Hydrology and Earth System Sciences, 6(3), 583-606 (2002) C EGS

\title{
The Integrated Catchments model of Phosphorus dynamics (INCA-P), a new approach for multiple source assessment in heterogeneous river systems: model structure and equations
}

\author{
A.J. Wade, P.G. Whitehead and D. Butterfield \\ Aquatic Environments Research Centre, Department of Geography, University of Reading, Reading, RG6 6AB, UK \\ Email for corresponding author: andrew.wade4@btinternet.com
}

\begin{abstract}
A new model has been developed for assessing the effects of multiple sources of phosphorus on the water quality and aquatic ecology in heterogeneous river systems. The Integrated Catchments model for Phosphorus (INCA-P) is a process-based, mass balance model that simulates the phosphorus dynamics in both the plant/soil system and the stream. The model simulates the spatial variations in phosphorus export from different land use types within a river system using a semi-distributed representation, thereby accounting for the impacts of different land management practices, such as organic and inorganic fertiliser and wastewater applications. The land phase of INCA-P includes a simplified representation of direct runoff, soilwater and groundwater flows, and the soil processes that involve phosphorus. In addition, the model includes a multi-reach in-stream component that routes water down the main river channel. It simulates Organic and Inorganic Phosphorus concentrations in the land phase, and Total Phosphorus (dissolved plus particulate phosphorus) concentrations in the in-stream phase. Instream Soluble Reactive Phosphorus concentrations are determined from the Total Phosphorus concentrations and the macrophyte, epiphyte and algal biomasses are simulated also. This paper describes the model structure and equations, the limitations and the potential utility of the approach.
\end{abstract}

Keywords: modelling, water quality, phosphorus, soluble reactive phosphorus, basin management

\section{Introduction}

Most freshwater systems are phosphorus (P) limited and hence there are concerns that increased $\mathrm{P}$ loads to a water body can affect the composition and diversity of aquatic plant species and attached algae and phytoplankton by changing the competitive balance, both between the plants, algae and phytoplankton and between the different species of each (Mainstone et al., 2000). In addition, nitrogen (N), generally in the form of nitrate $\left(\mathrm{NO}_{3}\right)$, is of concern because it also contributes to nutrient enrichment and elevated concentrations render water unsuitable for drinking. Soluble Reactive Phosphorus (SRP) is derived from both point and diffuse sources, the relative contributions of which are highly variable in space and time. In contrast, $\mathrm{NO}_{3}$ is derived predominantly from diffuse (agricultural) sources (Jarvie et al., 2002).

Water quality lies at the centre of European Union (EU) environment policy and is intimately linked to the hydrogeological and hydro-ecological functioning of river systems. As part of EU legislation that includes the Water Framework Directive, it is necessary to regulate the $\mathrm{N}$ and $\mathrm{P}$ loads entering lake and river systems considered sensitive to nutrient inputs. The purpose of such regulation is to help mitigate and prevent the problems associated with nutrient enriched water bodies, such as eutrophication and to reduce the water treatment costs for producing water suitable for industrial and public consumption (EC, 2000). Moreover, control measures to regulate the $\mathrm{N}$ and $\mathrm{P}$ sources are required at the local, regional and national scale to address spatial variations in water quality, whilst maintaining a viable local and national economy.

In the UK, such control measures are of major importance for lowland catchments, particularly in the south and east of England, where the land use is dominated by intensive agriculture and the growing population results in a greater input of nutrients into river systems from Sewage Treatment 
Works (STWs). In this region, high evaporation rates coupled with low rainfall reduce the dilution capacity of the rivers, further compounding the enrichment problem (Marsh and Sanderson, 1997). Given the costs involved in reducing $\mathrm{N}$ and $\mathrm{P}$ loads, mathematical models are used to aid the understanding of freshwater $\mathrm{N}$ and $\mathrm{P}$ dynamics and to make predictions of future changes in the water quality and ecology under likely scenarios. However, though models of $\mathrm{P}$ dynamics have been created, these have tended to address the eutrophication problem in lakes or reservoir systems (Vollenweider, 1975; Kao et al., 1998), or simulate $\mathrm{P}$ transport and retention in small-scale, agricultural systems (Gburek and Sharpley, 1998). Moreover, of the models that do simulate $\mathrm{P}$ dynamics in both the land and stream components of a catchment, none simulates the impact of $\mathrm{P}$ on the aquatic ecology.

This paper describes a new model of $\mathrm{P}$ dynamics in river systems named The Integrated Catchments model for Phosphorus (INCA-P), designed to investigate the transport and retention of $\mathrm{P}$ in the terrestrial and aquatic environment, and the impacts of the P load on the in-stream macrophyte and algal biomass. This new model builds on the established Integrated Nitrogen in Catchments model, INCA which is a dynamic, process-based hydrochemical model that simulates $\mathrm{N}$ in river systems and plot studies, and the 'Kennet' model which simulates in-stream $\mathrm{P}$ and macrophyte/epiphyte dynamics (Whitehead et al., 1998a, b; Wade et al., 2002a). As such, INCA-P represents an advance towards a generalised framework for simulating water quality determinands in heterogeneous river systems, which started with nitrogen and the INCA model and which could be extended to other determinands.

\section{The INCA-P model}

\section{MODEL OVERVIEW}

INCA-P is a dynamic, mass-balance model which tracks the temporal variations in the hydrological flowpaths and $\mathrm{P}$ transformations and stores, in both the land and in-stream components of the river catchment. INCA-P provides the following outputs:

- daily and annual land-use specific organic and inorganic-P fluxes $\left(\mathrm{kg} \mathrm{Pha}^{-1} \mathrm{yr}^{-1}\right)$ for all transformation processes and stores within the land phase;

- daily time series of land-use specific flows $\left(\mathrm{m}^{3} \mathrm{~s}^{-1}\right)$, and organic and inorganic-P concentrations $\left(\mathrm{mg} \mathrm{P}^{-1}\right)$ in the soil and groundwaters and in direct runoff;

- daily time series of flows, Total Phosphorus (TP), Soluble Reactive Phosphorus (SRP) (mg $\mathrm{P}^{-1}$ ) and chlorophyll- $a$ concentrations ( $\mu \mathrm{g} \mathrm{Chl}$ ' $\mathrm{a}$ ' $\mathrm{l}^{-1}$ ) and macrophyte biomass $\left(\mathrm{g} \mathrm{C} \mathrm{m}^{-2}\right)$ at selected sites along a river;

- profiles of flow and $\mathrm{P}$ concentrations along a river at selected sites;

- cumulative frequency distributions of flow and P concentrations at selected sites;

- detailed mass-balance checks.

Spatial data describing the major land use types are required in addition to time series inputs (Table 1). The required time series inputs are:

- the hydrology, namely the Soil Moisture Deficit (mm), Hydrologically Effective Rainfall (mm day ${ }^{-1}$ ), Air Temperature $\left({ }^{\circ} \mathrm{C}\right)$ and Actual Precipitation $\left(\mathrm{mm} \mathrm{day}^{-1}\right)$. These data are usually obtained from the MORECS model (Hough et al., 1997);

- data describing land management practices, namely estimates of growing season for different crop and vegetation types, and fertiliser application quantities and timings which are derived from the Fertiliser Manufacturers' Association (1994) and local knowledge, respectively;

- the flow rates and SRP concentrations of sewage effluent inputs.

The model has an interface designed to permit the inclusion of detailed time series data describing growing seasons, fertiliser and STW effluent inputs if available, or alternatively to accept single lumped values thereby allowing the application of the model to systems that are data rich or poor, respectively. To describe the spatial variations in the rainfall, soil moisture deficit and air temperature within a catchment, multiple hydrological time series can be loaded if available.

There are four components to the INCA-P model:

- a GIS interface that defines the subcatchment boundaries and calculates the area of each land-use type within each sub-catchment;

- a land-phase hydrological model that calculates the flow of effective rainfall through soil water and groundwater stores and as direct runoff. This component drives the water and $\mathrm{P}$ fluxes through the catchment;

- the land-phase P model that simulates P transformations and stores in the soil and groundwater of the catchment;

- the in-stream P model that simulates the dilution and in-stream P transformations, and the corresponding algal, epiphyte and macrophyte growth response. 
Table 1. The input data requirements of INCA-P, and examples of typical data sources. *The Centre for Ecology and Hydrology subsumed the Institute of Terrestrial Ecology in 2000.

\begin{tabular}{|c|c|c|c|}
\hline Data & Description & Example Source & Reference \\
\hline $\begin{array}{l}\text { TP and SRP streamwater } \\
\text { concentrations. }\end{array}$ & $\begin{array}{l}\text { Spot samples taken at points } \\
\text { within river system. }\end{array}$ & $\begin{array}{l}\text { Environment Agency } \\
\text { routine monitoring } \\
\text { research studies }\end{array}$ & Jarvie et al., 2002 \\
\hline Land use & $\begin{array}{l}\text { Classification at resolution } \\
\text { of } 1 \mathrm{~km}^{2} \text { grid. }\end{array}$ & $\begin{array}{l}\text { Institute of Terrestrial Ecology* } \\
\text { Land Survey of Great Britain }\end{array}$ & Barr et al., 1993 \\
\hline Precipitation & Daily time series & $\begin{array}{l}\text { Environment Agency, } \\
\text { Meteorological Office. }\end{array}$ & \\
\hline Discharge & Daily time series & Environment Agency & \\
\hline Flow velocity & $\begin{array}{l}\text { Occasional measurements } \\
\text { for flow ratings }\end{array}$ & Environment Agency & \\
\hline $\begin{array}{l}\text { MORECS rainfall, } \\
\text { temperature and soil } \\
\text { moisture }\end{array}$ & Daily time series (derived) & Meteorological Office. & Hough et al., 1997 \\
\hline Base flow index & $\begin{array}{l}\text { Derived for each flow gauge } \\
\text { and extrapolated to other } \\
\text { tributaries }\end{array}$ & $\begin{array}{l}\text { Centre for Ecology and } \\
\text { Hydrology }\end{array}$ & Gustard et al., 1987 \\
\hline $\begin{array}{l}\text { Fertiliser Practice: } \\
\text { Application }\end{array}$ & Survey & $\begin{array}{l}\text { Fertiliser Manufacturers' } \\
\text { Association }\end{array}$ & $\begin{array}{l}\text { Fertiliser Manufacturers' } \\
\text { Association, } 1994\end{array}$ \\
\hline Fertiliser Practice: Timing & Survey & Local knowledge & \\
\hline Growing season & Survey & Local knowledge & \\
\hline
\end{tabular}

The land-phase component model was developed to simulate a generic $1 \mathrm{~km}^{2}$ cell (Fig. 1). However, since INCA-P is semi-distributed rather than fully-distributed, the catchment is not decomposed into an array of cells on a grid basis: the flow of water and $\mathrm{P}$ is not routed between cells as with fully-distributed models such as the Système Hydrologique Européen (Abbot et al., 1986). Instead, the catchment is decomposed into three spatial levels (Fig. 2). At level 1, which equates to the largest spatial scale of the three, the catchment is decomposed into sub-catchments. At level 2, each sub-catchment is further decomposed into a maximum of six land use classes; this idea equates to that of a Functional Unit Network (FUN) (Neal, 1997; Wade et al., 2001). At the third level, the generic cell is then applied to each land-use type within each sub-catchment. Generalised equations define the $\mathrm{P}$ trans-formations and stores within the cell, and six user-defined parameter sets derived through calibration are used to simulate the differences between the land-use types, with one parameter set mapping to one land-use type. Thus, by calibrating equation parameters using experimental or field data available in the literature, the $\mathrm{P}$ fluxes from each transformation is determined. The numerical method for solving the equations is based on the fourth-order RungeKutta technique, which allows a simultaneous solution of the model equations thereby ensuring that no single process represented by the equations takes precedence over another.

To estimate the water and $\mathrm{P}$ outputs from each land-use type within each sub-catchment, the volume and load output from the cell model is multiplied by the land-use area, and the outputs from each land use are summed to provide a total sub-catchment volume and load. The resultant volume and load are then fed sequentially into a multi-reach river model.

The fertiliser, wastewater, slurry and livestock P inputs to the cell model vary with land-use type to simulate the variations in land management practice. In addition, the effective rainfall, soil moisture and temperature can also 


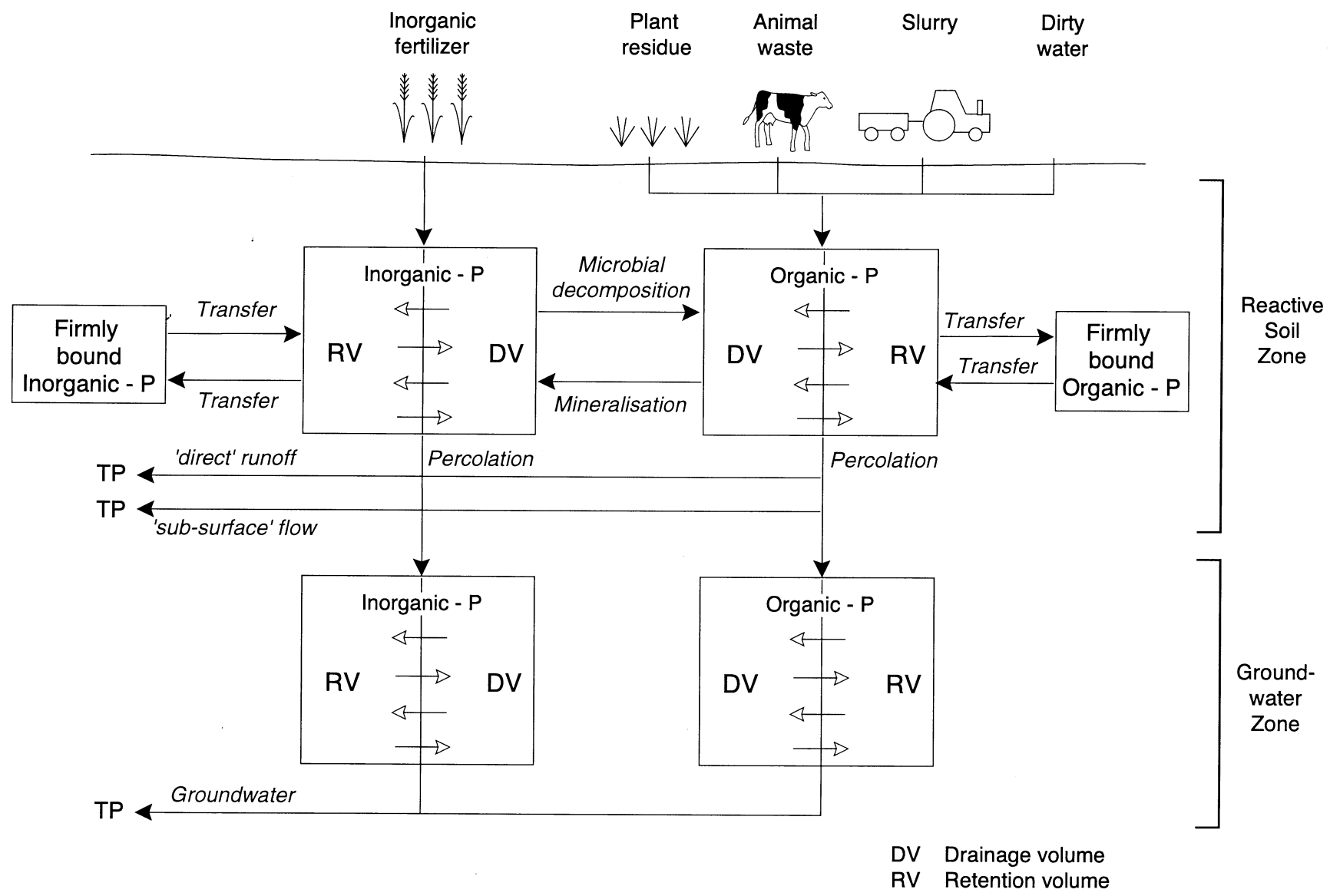

Fig. 1. Phosphorus inputs, processes and outputs in the direct runoff, soil and groundwater stores in the cell model of the land-phase component. TP = Total Phosphorus.

vary between sub-catchments. Thus, it is possible to simulate the spatial variations in land management practice and hydrological inputs to some degree although it is a necessary assumption of this model structure that:

- the fertiliser, wastewater, slurry and livestock inputs are the same for a particular land-use type, irrespective of the location within the catchment;

- the $\mathrm{P}$ process rates are the same irrespective of the location within the catchment, although they can still vary according to spatial variations in the soil moisture and temperature;

- the initial stores of water and P associated with each land-use type are the same irrespective of the location within the catchment.

This simplified representation of the $\mathrm{P}$ dynamics expected in a real river system was chosen to reduce the model's complexity, the data requirements and the time taken for each model run. Given the complex and highly heterogeneous nature of flow pathways, $\mathrm{P}$ processes and stores, it is uncertain if building a more realistic representation would improve model performance. Moreover, the hydrological and $\mathrm{N}$ process simulations produced by the INCA model, which uses the same assumptions and structure appear adequate (Whitehead et al., 1998b; Wade et al., 2002b). Each of the four components of INCA-P is described in detail below.

\section{THE GIS INTERFACE FOR LAND USE AND}

\section{SUBCATCHMENT BOUNDARIES}

To apply INCA-P to a river system, the main channel is divided into reaches, typically based on the locations of flow or water chemistry sampling locations, or other points of interest. In the case of UK applications, the land area draining into each reach is then derived using the Institute of Hydrology's Digital Terrain Model and Geographical Information System (GIS) algorithms (Morris and Flavin, 1994). The sub-catchment boundaries are then overlaid onto 


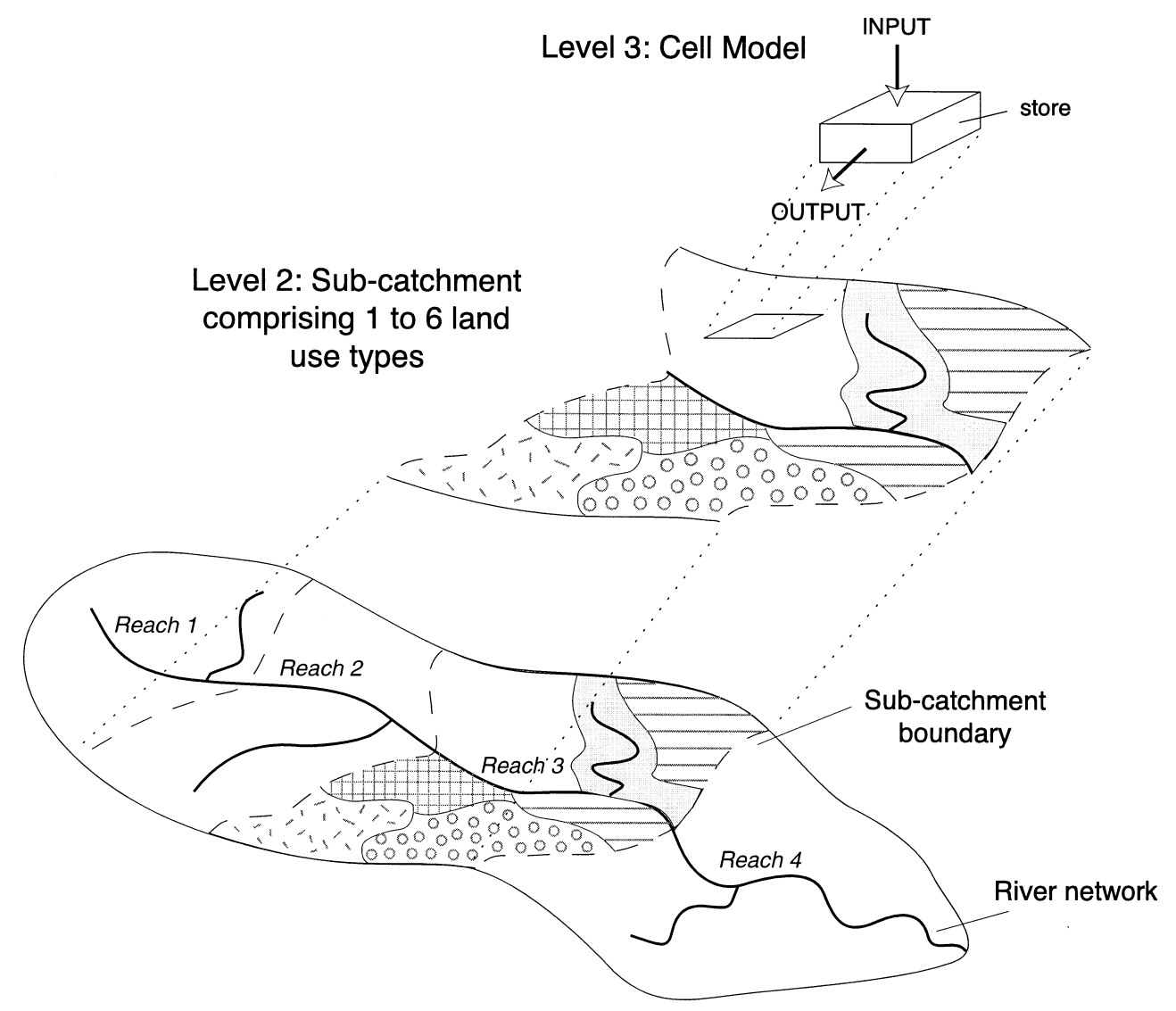

Level 1: River catchment

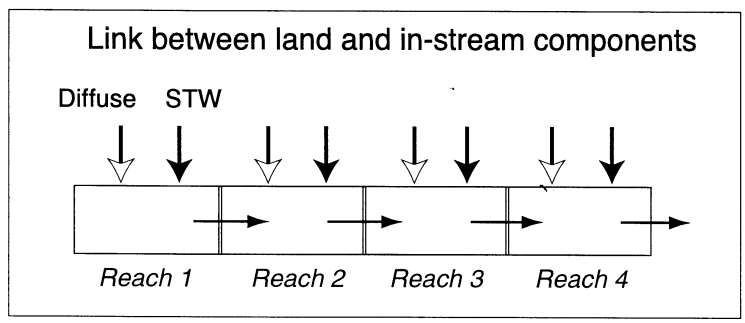

Fig. 2. The land-phase component model structure. At level 1 the catchment is decomposed into sub-catchments. At level 2, the sub-catchments are sub-divided into a maximum of 6 different land-use types. At level three, the soil $P$ transformations and stores are simulated using the cell model. The inset diagram also shows the link between the land-phase and in-stream components at level 1: the diffuse inputs to the stream from the land-phase are added to STW point source input in each reach and routed downstream.

the Institute of Terrestrial Ecology's (ITE) Land Cover Map of Great Britain, which is simplified into the six land-use categories: forest, short vegetation (ungrazed), short vegetation (grazed, but not fertilised), short vegetation (fertilised), arable and urban (Whitehead et al., 1998a). These classes were adequate in capturing the spatial variations when modelling nitrogen when using INCA, and therefore are used again in the initial development of INCA-P (Wade et al., 2002b). Moreover, the definitions of the six land use classes are not rigid, and may be changed for the INCA-P applications.

\section{THE LAND-PHASE HYDROLOGICAL MODEL}

The MORECS soil moisture and evaporation accounting model is used to convert the actual precipitation time series into an 'effective' rainfall time series (HER) (Hough et al., 1997). The effective rainfall is the water that penetrates the soil surface allowing for interception and evaporation loses. The advantage of the MORECS model is that a daily time series of soil moisture deficit is also derived at the same time as the HER, providing essential information for modelling the soil moisture dependent $\mathrm{P}$ transformations. The generic cell is split into three units that are defined 
according to the major vertical and lateral hydrological pathways likely within a catchment: direct runoff, subsurface drainage through the soils and groundwater drainage. The 'direct runoff' pathway accounts for overland flow, drain and ditch flows and flow over impermeable surfaces, thereby providing a mechanism for the rapid transfer of phosphorus into the main river channel. Direct runoff, in INCA-P, equates to the idea of saturation overland flow, and is assumed to occur when the flow from the soil store exceeds a user defined threshold, $\Delta$. The soil reactive zone is assumed to leach water to the deeper groundwater zone and the river. The split between the volume of water stored in the soil and the groundwater is calculated using the Base Flow Index (Gustard et al., 1987; Wade et al., 2002b).

In INCA-P, the soil drainage volume represents the water stored in the soil that responds rapidly to water inflow. As such, it may be thought of as macropore or piston flow: the flow that most strongly influences a rising hydrograph limb. The soil retention volume represents the water stored in the soil that responds more slowly and may make up the majority of water storage in the soil. As such, this water may be thought of as stored in the soil micropores, and therefore dependent on the soil wetting and drying characteristics. The groundwater volume represents a deeper store in an aquifer, and the residence time may reflect a piston flow effect rather than a more typical groundwater turnover time. The principal residence times for each of the three stores are determined through model calibration.

The flow model is described by Eqns. (1) to (3), the equations that track the mass-balance are listed in Appendix A and the nomenclature is listed in Tables 2 to 5 .

Flow change from direct runoff

$$
\frac{d x_{1}}{d t}=\frac{\alpha x_{2}-x_{1}}{T_{1}}
$$

if $x_{2} \geq \Delta$ then input flow $=\alpha x_{2}$ or if $x_{2}<\Delta$ then input flow $=0$.

Flow change from soil

$$
\frac{d x_{2}}{d t}=\frac{U_{1}-x_{2}}{T_{2}}
$$

Flow change from groundwater

$$
\frac{d x_{3}}{d t}=\frac{\beta x_{2}-x_{3}}{T_{3}}
$$

where $x_{1}, x_{2}$ and $x_{3}$ are the output flows $\left(\mathrm{m}^{3} \mathrm{~s}^{-1} \mathrm{~km}^{-2}\right)$ from the direct runoff, soilwater and groundwater stores, respectively and $U_{1}$ is the hydrologically effective rainfall $\left(\mathrm{m}^{3} \mathrm{~s}^{-1} \mathrm{~km}^{-2}\right)$ as defined by Whitehead et al., (1998a). $T_{1}, T_{2}$ and $T_{3}$ are the time constants associated with the three stores (days), $\alpha$ is the proportion of the output soilwater flow entering the direct runoff flowpath, $\beta$ is the Base Flow Index and $\Delta$ is the direct runoff threshold flow $\left(\mathrm{m}^{3} \mathrm{~s}^{-1} \mathrm{~km}^{-2}\right)$. Any input of direct runoff to the groundwater is assumed to occur via the soil water.

The soil retention volume per $\mathrm{km}^{2}, V_{r}\left(\mathrm{~m}^{3} \mathrm{~km}^{-2}\right)$ is linearly dependent on the Soil Moisture Deficit, $U_{5}(\mathrm{~mm})$ at time, $t$ such that:

$$
V_{r}=V_{r, \text { max }}-U_{5} .1000
$$

where $V_{r, \text { max }}=d \times p \times 10^{6}$

The factor of $10^{6}\left(\mathrm{~m}^{2} \mathrm{~km}^{-2}\right)$ is included to maintain the dimensions of Eqn. (5) in which the units of $V_{r, \max }$ are $\left(\mathrm{m}^{3} \mathrm{~km}^{-2}\right)$. For a $1 \mathrm{~km}^{2}$ cell, $V_{r}$ can be expressed as

$$
A . V_{r}=A\left(V_{r, \text { max }}-U_{5} .1000\right)
$$

where $A . V_{r \text { max }}$ is the maximum size of the retention volume $\left(\mathrm{m}^{3}\right), A$ is the cell area $\left(\mathrm{km}^{2}\right), d$ is the soil depth (m) and $p$ is the soil porosity $(\varnothing)$. The soil water drainage volume, $x_{16}$ $\left(\mathrm{m}^{3} \mathrm{~km}^{-2}\right)$ is defined in Appendix A, Eqn. (A.5).

\section{THE LAND-PHASE P MODEL}

The three hydrological stores that form the land-phase hydrological model also form the basis for simulating phosphorus storage within the catchment: INCA-P tracks the organic and inorganic $\mathrm{P}$, within the direct runoff, soil and groundwater stores. The key processes determining the transformation and retention of $\mathrm{P}$ within the land-phase are shown in Fig. 1. INCA-P models plant uptake of organic and inorganic $\mathrm{P}$ mineralisation, immobilisation and the transformations between firmly bound and available $\mathrm{P}$ within each land-use type within each sub-catchment. The plant uptake process varies both in terms of rate and seasonal pattern of uptake to account for the physiological differences between semi-natural vegetation and more intensively managed forestry and farmland. In addition, the plant uptake, mineralisation and immobilisation are soil moisture and temperature dependent and can be set to vary with land-use type.

The inputs from inorganic $\mathrm{P}$ fertiliser, wastewater, slurry and the waste from grazing animals are represented as a daily time series of mass $\left(\mathrm{kg} \mathrm{P} \mathrm{ha}^{-1} \mathrm{day}^{-1}\right)$ inputs and are read from a file, if such data are available. Thus, it is possible to simulate multiple fertiliser applications within each year, and multiple plant-growth periods can also be specified. Alternatively, average input rates can be specified for defined time periods. In the groundwater zone, it is assumed that no biogeochemical reactions occur and that a mass 
Table 2. Land-phase equation variables

\begin{tabular}{|c|c|c|}
\hline Symbol & Definition & Units \\
\hline $\mathrm{dx}_{1} / \mathrm{dt}$ & Change in direct runoff & $\mathrm{m}^{3} \mathrm{~s}^{-1} \mathrm{day}^{-1} \mathrm{~km}^{-2}$ \\
\hline $\mathrm{dx}_{2} / \mathrm{dt}$ & Change in soil flow & $\mathrm{m}^{3} \mathrm{~s}^{-1} \mathrm{day}^{-1} \mathrm{~km}^{-2}$ \\
\hline $\mathrm{dx}_{3} / \mathrm{dt}$ & Change in groundwater flow & $\mathrm{m}^{3} \mathrm{~s}^{-1} \mathrm{day}^{-1} \mathrm{~km}^{-2}$ \\
\hline $\mathrm{dx}_{4}^{3} / \mathrm{dt}$ & Change in readily-available organic phosphorus mass in soil & $\mathrm{kg} \mathrm{P}$ day $^{-1} \mathrm{~km}^{-2}$ \\
\hline $\mathrm{dx}_{5} / \mathrm{dt}$ & Change in readily-available inorganic phosphorus mass in soil & $\mathrm{kg} \mathrm{P}$ day $^{-1} \mathrm{~km}^{-2}$ \\
\hline $\mathrm{dx}_{6}^{3} / \mathrm{dt}$ & Change in readily-available organic phosphorus mass in groundwater & $\mathrm{kg} \mathrm{P}$ day $^{-1} \mathrm{~km}^{-2}$ \\
\hline $\mathrm{dx}_{7} / \mathrm{dt}$ & Change in readily-available inorganic phosphorus mass in groundwater & $\mathrm{kg} \mathrm{P}$ day $^{-1} \mathrm{~km}^{-2}$ \\
\hline $\mathrm{dx}_{8} / \mathrm{dt}$ & Change in readily-available organic phosphorus mass in direct runoff & $\mathrm{kg} P$ day $^{-1} \mathrm{~km}^{-2}$ \\
\hline $\mathrm{dx}_{9} / \mathrm{dt}$ & Change in readily-available inorganic phosphorus mass in direct runoff & $\mathrm{kg} \mathrm{P}$ day $^{-1} \mathrm{~km}^{-2}$ \\
\hline $\mathrm{dx}_{10} / \mathrm{dt}$ & Change in firmly-bound organic phosphorus mass in soil & $\mathrm{kg} \mathrm{P}$ day $^{-1} \mathrm{~km}^{-2}$ \\
\hline $\mathrm{dx}_{11} / \mathrm{dt}$ & Change in firmly-bound inorganic phosphorus mass in soil & $\mathrm{kg} \mathrm{P}$ day $^{-1} \mathrm{~km}^{-2}$ \\
\hline $\mathrm{dx}_{12} / \mathrm{dt}$ & Change in total organic phosphorus mass input into system & $\mathrm{kg} \mathrm{P}$ day $^{-1} \mathrm{~km}^{-2}$ \\
\hline $\mathrm{dx}_{13}^{12} / \mathrm{dt}$ & Change in total organic phosphorus mass output from system & $\mathrm{kg} P$ day ${ }^{-1} \mathrm{~km}^{-2}$ \\
\hline $\mathrm{dx}_{14} / \mathrm{dt}$ & Change in total inorganic phosphorus mass input into system & $\mathrm{kg} \mathrm{P}$ day $^{-1} \mathrm{~km}^{-2}$ \\
\hline $\mathrm{dx}_{15} / \mathrm{dt}$ & Change in total inorganic phosphorus mass output from system & $\mathrm{kg} \mathrm{P}$ day $^{-1} \mathrm{~km}^{-2}$ \\
\hline $\mathrm{dx}_{16} / \mathrm{dt}$ & Soil water volume change & $\mathrm{m}^{3} \mathrm{day}^{-1} \mathrm{~km}^{-2}$ \\
\hline $\mathrm{dx}_{17}^{10} / \mathrm{dt}$ & Groundwater volume change & $\mathrm{m}^{3} \mathrm{day}^{-1} \mathrm{~km}^{-2}$ \\
\hline $\mathrm{dx}_{18} / \mathrm{dt}$ & Direct runoff volume change & $\mathrm{m}^{3} \mathrm{day}^{-1} \mathrm{~km}^{-2}$ \\
\hline $\mathrm{dx}_{19} / \mathrm{dt}$ & Total water flow input to the system & $\mathrm{m}^{3} \mathrm{day}^{-1} \mathrm{~km}^{-2}$ \\
\hline $\mathrm{dx}_{20} / \mathrm{dt}$ & Total water flow output from the system & $\mathrm{m}^{3}$ day $^{-1} \mathrm{~km}^{-2}$ \\
\hline $\mathrm{dx}_{21}^{20} / \mathrm{dt}$ & Change in organic phosphorus plant-uptake & $\mathrm{kg} \mathrm{P}$ day $^{-1} \mathrm{~km}^{-2}$ \\
\hline $\mathrm{dx}_{22} / \mathrm{dt}$ & Change in immobilisation & $\mathrm{kg} \mathrm{P}$ day $^{-1} \mathrm{~km}^{-2}$ \\
\hline $\mathrm{dx}_{23} / \mathrm{dt}$ & Change in mineralisation & $\mathrm{kg} \mathrm{P}$ day $^{-1} \mathrm{~km}^{-2}$ \\
\hline $\mathrm{dx}_{24} / \mathrm{dt}$ & Change in organic phosphorus plant-uptake & $\mathrm{kg} \mathrm{P}$ day $^{-1} \mathrm{~km}^{-2}$ \\
\hline $\mathrm{x}_{1}$ & Direct runoff & $\mathrm{m}^{3} \mathrm{~s}^{-1} \mathrm{~km}^{-2}$ \\
\hline $\mathrm{x}_{2}$ & Soil outflow & $\mathrm{m}^{3} \mathrm{~s}^{-1} \mathrm{~km}^{-2}$ \\
\hline $\mathrm{x}_{3}$ & Groundwater outflow & $\mathrm{m}^{3} \mathrm{~s}^{-1} \mathrm{~km}^{-2}$ \\
\hline $\mathrm{x}_{4}^{3}$ & Readily-available organic phosphorus stored in soil & $\mathrm{kg} \mathrm{P} \mathrm{km}{ }^{-2}$ \\
\hline $\mathrm{x}_{5}$ & Readily-available inorganic phosphorus stored in soil & $\mathrm{kg} \mathrm{P} \mathrm{km} \mathrm{km}^{-2}$ \\
\hline $\mathrm{x}_{6}$ & Readily-available organic phosphorus stored in groundwater & $\mathrm{kg} \mathrm{P} \mathrm{km}^{-2}$ \\
\hline $\mathrm{x}_{7}$ & Readily-available inorganic phosphorus stored in groundwater & $\mathrm{kg} \mathrm{P} \mathrm{km}^{-2}$ \\
\hline $\mathrm{x}_{8}$ & Readily-available organic phosphorus stored in direct runoff & $\mathrm{kg} \mathrm{P} \mathrm{km}^{-2}$ \\
\hline $\mathrm{x}_{9}$ & Readily-available inorganic phosphorus stored in direct runoff & $\mathrm{kg} \mathrm{P} \mathrm{km} \mathrm{km}^{-2}$ \\
\hline $\mathrm{x}_{10}$ & Firmly-bound organic phosphorus stored in soil & $\mathrm{kg} \mathrm{P} \mathrm{km}^{-2}$ \\
\hline $\mathrm{x}_{11}$ & Firmly-bound inorganic phosphorus stored in soil & $\mathrm{kg} \mathrm{P} \mathrm{km}^{-2}$ \\
\hline $\mathrm{x}_{12}$ & Accumulated total organic phosphorus input to the system & $\mathrm{kg} \mathrm{P} \mathrm{km}^{-2}$ \\
\hline $\mathrm{x}_{13}$ & Accumulated total organic phosphorus output from the system & $\mathrm{kg} \mathrm{P} \mathrm{km} \mathrm{km}^{-2}$ \\
\hline $\mathrm{x}_{14}$ & Accumulated total inorganic phosphorus input to the system & $\mathrm{kg} \mathrm{P} \mathrm{km} \mathrm{km}^{-2}$ \\
\hline $\mathrm{x}_{15}$ & Accumulated total inorganic phosphorus output from system & $\mathrm{kg} \mathrm{P} \mathrm{km}^{-2}$ \\
\hline $\mathrm{x}_{16}$ & Soil water volume & $\mathrm{m}^{3} \mathrm{~km}^{-2}$ \\
\hline$x_{17}$ & Groundwater volume & $\mathrm{m}^{3} \mathrm{~km}^{-2}$ \\
\hline $\mathrm{x}_{18}$ & Direct runoff volume & $\mathrm{m}^{3} \mathrm{~km}^{-2}$ \\
\hline $\mathrm{x}_{19}$ & Accumulated water input to the system since simulation start & $\mathrm{m}^{3} \mathrm{~km}^{-2}$ \\
\hline $\mathrm{x}_{20}$ & Accumulated water output from the system since simulation start & $\mathrm{m}^{3} \mathrm{~km}^{-2}$ \\
\hline $\mathrm{x}_{21}$ & Accumulated mass associated with organic phosphorus plant-uptake & $\mathrm{kg} \mathrm{P} \mathrm{km}^{-2}$ \\
\hline$x_{22}$ & Accumulated mass associated with immobilisation & $\mathrm{kg} \mathrm{P} \mathrm{km} \mathrm{k}^{-2}$ \\
\hline $\mathrm{x}_{23}$ & Accumulated mass associated with mineralisation & $\mathrm{kg} \mathrm{P} \mathrm{km}^{-2}$ \\
\hline$x_{24}$ & Accumulated mass associated with organic phosphorus plant-uptake & $\mathrm{kg} \mathrm{P} \mathrm{km}^{-2}$ \\
\hline
\end{tabular}


Table 3. Land-phase equations. User supplied inputs as time series.

\begin{tabular}{lll}
\hline Symbol & Definition & Units \\
\hline $\mathrm{U}_{1}$ & Input rainfall & $\mathrm{m}^{3} \mathrm{~s}^{-1} \mathrm{~km}^{-2}$ \\
$\mathrm{U}_{2}$ & $\begin{array}{l}\text { Input Organic Phosphorus load (includes input from livestock, fertiliser, } \\
\text { wastewater and slurry) }\end{array}$ & \\
& Input Inorganic Phosphorus load (includes input from fertiliser) & $\mathrm{kg} \mathrm{P} \mathrm{ha}^{-1} \mathrm{day}^{-1}$ \\
$\mathrm{U}_{3}$ & Air temperature & $\mathrm{kg} \mathrm{P} \mathrm{ha}^{-1} \mathrm{day}^{-1}$ \\
$\mathrm{U}_{4}$ & Soil Moisture Deficit & ${ }^{\circ} \mathrm{C}$ \\
$\mathrm{U}_{5}$ & & $\mathrm{~mm}$ \\
\hline
\end{tabular}

Table 4. Land-phase equations. User supplied inputs as parameters. ${ }^{*}$ The initial conditions within the model

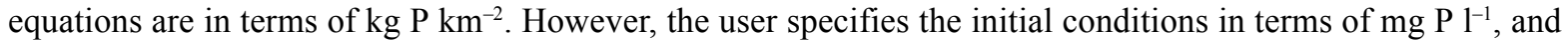
these concentrations are converted to $\mathrm{kg} \mathrm{P} \mathrm{km}^{-2}$ in the model.

\begin{tabular}{|c|c|c|}
\hline Symbol & Definition & Units \\
\hline$\alpha$ & Direct runoff fraction & $(\varnothing)$ \\
\hline$\beta$ & Base Flow Index & $(\varnothing)$ \\
\hline$\Delta$ & Direct runoff threshold & $\mathrm{m}^{3} \mathrm{~s}^{-1} \mathrm{~km}^{-2}$ \\
\hline $\mathrm{T}_{1}$ & Direct runoff residence time & days \\
\hline $\mathrm{T}_{2}$ & Soil water residence time & days \\
\hline $\mathrm{T}_{3}$ & Groundwater residence time & days \\
\hline $\mathrm{C}_{1}$ & Plant organic phosphorus uptake rate & $m$ day $^{-1}$ \\
\hline $\mathrm{C}_{2}$ & Immobilisation rate & $\mathrm{m} \mathrm{day}^{-1}$ \\
\hline $\mathrm{C}_{3}$ & Mineralisation rate & $\mathrm{m} \mathrm{day}^{-1}$ \\
\hline $\mathrm{C}_{4}$ & Conversion rate of readily available organic phosphorus to firmly bound & $\mathrm{m} \mathrm{day}^{-1}$ \\
\hline $\mathrm{C}_{5}$ & Conversion rate of firmly bound organic phosphorus to readily available & $m$ day $^{-1}$ \\
\hline $\mathrm{C}_{6}$ & Plant inorganic phosphorus uptake rate & $\mathrm{m} \mathrm{day}^{-1}$ \\
\hline $\mathrm{C}_{7}$ & Conversion rate of readily available inorganic phosphorus to firmly bound & $\mathrm{m} \mathrm{day}^{-1}$ \\
\hline $\mathrm{C}_{8}$ & Conversion rate of firmly bound inorganic phosphorus to readily available & $\mathrm{m} \mathrm{day}^{-1}$ \\
\hline $\mathrm{C}_{9}$ & Start of growing season & day number \\
\hline $\mathrm{C}_{29}$ & Maximum air temperature difference between Summer and Winter & ${ }^{\circ} \mathrm{C}$ \\
\hline A & Area of cell $\left(1 \mathrm{~km}^{2}\right)$ & $\mathrm{km}^{2}$ \\
\hline $\mathrm{d}$ & Depth of soil & $\mathrm{m}$ \\
\hline $\mathrm{p}$ & Soil porosity & $(\varnothing)$ \\
\hline $\mathrm{SMD}_{\max }$ & Soil Moisture Deficit maximum value & $\mathrm{mm}$ \\
\hline $\mathrm{x}_{4,0}$ & Initial readily available organic phosphorus stored in soil* & $\mathrm{kg} \mathrm{P} \mathrm{km}{ }^{-2}$ \\
\hline $\mathrm{x}_{5,0}$ & Initial readily available inorganic phosphorus stored in soil* & $\mathrm{kg} \mathrm{P} \mathrm{km}^{-2}$ \\
\hline$x_{6,0}$ & Initial readily available organic phosphorus in groundwater* & $\mathrm{kg} \mathrm{P} \mathrm{km}^{-2}$ \\
\hline $\mathrm{x}_{7,0}$ & Initial readily available inorganic phosphorus in groundwater* & $\mathrm{kg} \mathrm{P} \mathrm{km}^{-2}$ \\
\hline $\mathrm{x}_{8,0}$ & Initial readily available organic phosphorus in direct runoff* & $\mathrm{kg} \mathrm{P} \mathrm{km}^{-2}$ \\
\hline $\mathrm{x}_{9,0}$ & Initial readily available inorganic phosphorus in direct runoff* & $\mathrm{kg} \mathrm{P} \mathrm{km}^{-2}$ \\
\hline $\mathrm{x}_{10,0}$ & Initial firmly bound organic phosphorus stored in soil* & $\mathrm{kg} \mathrm{P} \mathrm{km}{ }^{-2}$ \\
\hline $\mathrm{x}_{11,0}$ & Initial firmly bound inorganic phosphorus stored in soil* & $\mathrm{kg} \mathrm{P} \mathrm{km}^{-2}$ \\
\hline
\end{tabular}


Table 5. Model parameters and output concentrations calculated within the land-phase of the INCA-P model.

\begin{tabular}{lll}
\hline Symbol & Definition & Units \\
\hline $\mathrm{S}_{1}$ & Seasonal plant growth index & $(\varnothing)$ \\
$\mathrm{S}_{2}$ & Soil moisture factor & $(\varnothing)$ \\
$\mathrm{S}_{3}$ & Soil temperature & ${ }^{\circ} \mathrm{C}$ \\
$\mathrm{V}_{\mathrm{r}}$ & Soil retention volume & $\mathrm{m}^{3} \mathrm{~km}^{-2}$ \\
$\mathrm{~V}_{\mathrm{r}, \mathrm{max}}$ & Maximum soil retention volume & $\mathrm{m}^{3} \mathrm{~km}^{-2}$ \\
$\mathrm{a}_{1}$ & Soil water organic phosphorus concentration & $\mathrm{mg} \mathrm{P} \mathrm{l}^{-1}$ \\
$\mathrm{a}_{2}$ & Soil water inorganic phosphorus concentration & $\mathrm{mg} \mathrm{P} \mathrm{l}^{-1}$ \\
$\mathrm{a}_{3}$ & Groundwater organic phosphorus concentration & $\mathrm{mg} \mathrm{P} \mathrm{l}^{-1}$ \\
$\mathrm{a}_{4}$ & Groundwater inorganic phosphorus concentration & $\mathrm{mg} \mathrm{P} \mathrm{l}^{-1}$ \\
$\mathrm{a}_{5}$ & Direct Runoff organic phosphorus concentration & $\mathrm{mg} \mathrm{P} \mathrm{l}^{-1}$ \\
$\mathrm{a}_{6}$ & Direct Runoff inorganic phosphorus concentration & $\mathrm{mg} \mathrm{P} \mathrm{l}^{-1}$ \\
\hline
\end{tabular}

balance of organic and inorganic $\mathrm{P}$ is adequate.

The stores of firmly bound $\mathrm{P}$, in organic and inorganic forms are tracked separately from the $\mathrm{P}$ assumed to be more easily available for transportation or processing. The inorganic and organic P pools are tracked separately to account for the differences in biochemical cycling, retention and release via the hydrological flowpaths. This conceptualisation also fits in with other, more established models of the plant-soil system P dynamics such as ANIMO (Groenendyk and Kroes, 1999). Whilst it is recognised that $\mathrm{P}$ in particulate and soluble forms will move at different rates within the system, it is assumed that the soluble and particulate forms are in equilibrium. Given the uncertainty in the exchange mechanism between the two forms, this assumption was made to simplify the model structure and limit data requirements. The in-stream model requires the $P$ input to be specified as TP and therefore the masses of organic and inorganic $\mathrm{P}$ are summed before input to the instream component.

Initial conditions are required for the direct runoff, soilwater and groundwater organic and inorganic $\mathrm{P}$ concentrations and the user supplies these conditions. To some extent, these initial conditions represent the history of the catchment and the land use at that point in time. The equations for the land-phase component are as follows:

\section{Soil Store}

Change in readily available organic $\mathrm{P}$ mass in soil

$$
\begin{aligned}
& \frac{d x_{4}}{d t}=U_{2} \cdot 100-\frac{x_{2} x_{4} \cdot 86400}{V_{r}+x_{16}}-C_{1} S_{1} S_{2} \frac{x_{4}}{V_{r}+x_{16}} 10^{6} \\
& +C_{2} S_{2} \frac{x_{5}}{V_{r}+x_{16}} 10^{6}-C_{3} S_{2} \frac{x_{4}}{V_{r}+x_{16}} 10^{6}-\frac{d x_{10}}{d t}
\end{aligned}
$$

Change in readily available inorganic $\mathrm{P}$ mass in soil

$$
\begin{aligned}
& \frac{d x_{5}}{d t}=U_{3} .100-\frac{x_{2} x_{5} .86400}{V_{r}+x_{16}}-C_{6} S_{1} S_{2} \frac{x_{5}}{V_{r}+x_{16}} 10^{6} \\
& +C_{3} S_{2} \frac{x_{4}}{V_{r}+x_{16}} 10^{6}-C_{2} S_{2} \frac{x_{5}}{V_{r}+x_{16}} 10^{6}-\frac{d x_{11}}{d t}
\end{aligned}
$$

where $x_{4}$ and $x_{5}$ are the respective organic and inorganic $\mathrm{P}$ masses $\left(\mathrm{kg} \mathrm{P} \mathrm{km}^{-2}\right)$ stored in the soil and available to microbes, $x_{10}$ and $x_{11}$ are the respective firmly-bound organic and inorganic $\mathrm{P}$ masses $\left(\mathrm{kg} \mathrm{P} \mathrm{km}^{-2}\right), U_{2}$ and $U_{3}$ are the respective organic and inorganic $\mathrm{P}$ mass inputs $\left(\mathrm{kg} \mathrm{P} \mathrm{km}^{-2}\right)$. The terms $C_{1}, C_{6}, C_{2}, C_{3}$ and are the process rate parameters linked to organic and inorganic $P$ plant uptake, immobilisation and mineralisation, respectively. The terms $S_{1}$ and $S_{2}$ are defined in the following paragraphs and the other terms are defined previously.

As for $\mathrm{N}$ in INCA, plant $\mathrm{P}$ uptake is assumed to be dependent upon the amount of $\mathrm{P}$ available, up to a threshold value that represents the maximum uptake needed by the plant. The threshold value can be set by the user and may vary between land-use types.

$$
\text { Uptake }=C_{n} S_{1} S_{2} \frac{x_{m}}{V_{r}+x_{16}} 10^{6}
$$

where $C_{\mathrm{n}}$ is the uptake rate $\left(\right.$ days $\left.^{-1}\right)$ and $x_{m}$ is the available mass of $\mathrm{P}(\mathrm{kg} \mathrm{P}) . S_{1}$ is a seasonal plant growth index (Ø) (Hall and Harding, 1993), which simulates an increase and decrease in plant nutrient demand based on the time of year:

$$
S_{1}=0.66+0.34 \sin \left(2 \pi \frac{\left(\text { day } \cdot \text { of } \cdot \text { year }-C_{9}\right)}{365}\right)
$$

where $C_{9}$ is the day number associated with the start of the growing season. 
Plant uptake is also assumed to be dependent on the soil moisture where the soil moisture factor, $S_{2}(\varnothing)$ is defined as

$$
S_{2}=\frac{S M D_{\text {max }}-U_{5}}{S M D_{\text {max }}} \text { or } S_{2}=0 \text { if } U_{5}>S M D_{\text {max }}
$$

$S M D_{\text {max }}(\mathrm{mm})$ is the maximum soil moisture deficit within a land-use type at which a plant can extract water or at which the soil microbes are active. As such, this point may equate to the wilting point. If the daily soil moisture deficit exceeds the maximum then no $\mathrm{P}$ transfers will occur, either because the plants cannot extract water or the microbial activity is suspended. When the soils are wet and equal to or below the threshold, then the process rate is modified by the degree of soil wetness.

\section{Temperature dependency}

In addition, it is assumed that all the rate co-efficients are temperature dependent, such that

$$
C_{n}=C 1.047^{\left(S_{3}-20\right)}
$$

where $S_{3}$ is the soil temperature $\left({ }^{\circ} \mathrm{C}\right)$, calculated from a seasonal relationship dependent on air temperature, $U_{4}\left({ }^{\circ} \mathrm{C}\right)$ where

$$
S_{3}=U_{4}-C_{29} \sin \left(\frac{3}{2} \pi \frac{\text { dayno }}{365}\right)
$$

where $C_{29}$ is the maximum difference $\left({ }^{\circ} \mathrm{C}\right)$ between the summer and winter temperature (Green and Harding, 1979).

\section{Mineralisation and immobilisation}

The fluxes of $\mathrm{P}$ associated with mineralisation and immobilisation are defined as

$$
\begin{aligned}
& \text { Mineralisation }=C_{3} S_{2} \frac{x_{4}}{V_{r}+x_{16}} 10^{6} \\
& \text { Immobilisation }=C_{2} S_{2} \frac{x_{5}}{V_{r}+x_{16}} 10^{6}
\end{aligned}
$$

where all the terms have been defined previously. Both terms are soil moisture and temperature dependent, and a function of $\mathrm{P}$ concentration.

\section{Groundwater store}

Change in mass of organic phosphorus in groundwater

$$
\frac{d x_{6}}{d t}=\frac{\beta x_{2} x_{4} .86400}{V_{r}+x_{16}}-\frac{x_{3} x_{6} .86400}{x_{17}}
$$

Change in mass of inorganic phosphorus in groundwater

$$
\frac{d x_{7}}{d t}=\frac{\beta x_{2} x_{5} .86400}{V_{r}+x_{16}}-\frac{x_{3} x_{7} .86400}{x_{17}}
$$

where $x_{6}$ and $x_{7}$ are the masses of organic and inorganic $\mathrm{P}$ stored in the groundwater $\left(\mathrm{kg} \mathrm{P} \mathrm{km}^{-2}\right)$ and $x_{17}$ is the groundwater volume $\left(\mathrm{m}^{3} \mathrm{~km}^{-2}\right)$.

\section{Direct runoff}

Change in mass of organic phosphorus in direct runoff

$$
\frac{d x_{8}}{d t}=\frac{\alpha x_{2} x_{4} \cdot 86400}{V_{r}+x_{16}}-\frac{x_{1} x_{8} \cdot 86400}{x_{18}}
$$

Change in mass of inorganic phosphorus in direct runoff

$$
\frac{d x_{9}}{d t}=\frac{\alpha x_{2} x_{5} .86400}{V_{r}+x_{16}}-\frac{x_{1} x_{9} \cdot 86400}{x_{18}}
$$

where $x_{8}$ and $x_{9}$ are the masses of organic and inorganic $\mathrm{P}$ associated with the direct runoff $\left(\mathrm{kg} \mathrm{P} \mathrm{km}^{-2}\right)$ and $x_{18}$ is the direct runoff volume $\left(\mathrm{m}^{3} \mathrm{~km}^{-2}\right)$.

\section{Firmly bound phosphorus in soil store}

Change in mass of firmly-bound organic phosphorus in soil

$$
\frac{d x_{10}}{d t}=\frac{C_{4} x_{4} 10^{6}}{V_{r}+x_{16}}-\frac{C_{5} x_{10} 10^{6}}{V_{r}+x_{16}}
$$

Change in mass of firmly-bound inorganic phosphorus in soil

$$
\frac{d x_{11}}{d t}=\frac{C_{7} x_{5} 10^{6}}{V_{r}+x_{16}}-\frac{C_{8} x_{11} 10^{6}}{V_{r}+x_{16}}
$$

where $x_{10}$ and $x_{11}$ are the masses of organic and inorganic $\mathrm{P}$ associated with the firmly bound $\mathrm{P}$ stored in the soil $(\mathrm{kg} \mathrm{P}$ $\mathrm{km}^{-2}$ ). $C_{4}$ and $C_{7}$ are the transfer rates of organic and inorganic $\mathrm{P}$ respectively, from the readily available store to the firmly bound store. $C_{5}$ and $C_{8}$ are the transfer rates of organic and inorganic $\mathrm{P}$, from the firmly bound store to the readily available store.

\section{Calculation of concentrations}

The concentrations of inorganic and organic $\mathrm{P}$ in the three hydrological stores are calculated as the load divided by the volume of the store. For example, for organic phosphorus in the soil, $a_{1}\left(\mathrm{mg} \mathrm{P}^{-1}\right)$ :

$$
a_{1}=\frac{x_{4} \cdot 1000}{x_{16}+V_{r}}
$$


where $x_{4}$ is the mass output per day from the soil store, and $\left(x_{16}+V_{r}\right)$ is the volume of the soil store. The factor of 1000 arises because of the conversion units required to generate a concentration in $\mathrm{mg} \mathrm{P}^{-1}$.

\section{THE IN-STREAM P PROCESS MODEL}

The in-stream $P$ process model represents the major stores in the aquatic $\mathrm{P}$ cycle and the in-stream processes that determine the transfer of $\mathrm{P}$ between those stores (Fig. 3). This component is similar to the Kennet Model, though it has been written in terms of mass rather than concentration to overcome the mass-balance problems identified by Wade et al. (2002b). The in-stream model is a multi-reach, dynamic representation that operates on a daily time step. It simulates the mean daily flow, the Total Phosphorus (TP), Soluble Reactive Phosphorus (SRP), Boron and suspended sediment streamwater concentrations in the water column, the SRP concentrations in the pore water and TP associated with the river bed sediments. Boron was modelled because it is a chemically conservative tracer of point source inputs, and therefore valuable for testing in-stream mixing relationships (Neal et al., 2000; Wade et al., 2002c). The equation used to simulate Boron could be applied equally to any other determinand assumed to behave conservatively. For example chloride could be used although a correction may be needed for atmospheric sources. In addition, the model simulates the re-suspension of bed sediment, the deposition of suspended sediment and the effects of the $P$ concentrations on the growth of the macrophyte and epiphyte populations within the reach, and the subsequent feedback that such growth has on the water column TP and SRP concentrations. Inputs to the model are the flows and TP loads derived from the land phase component of INCA-P.

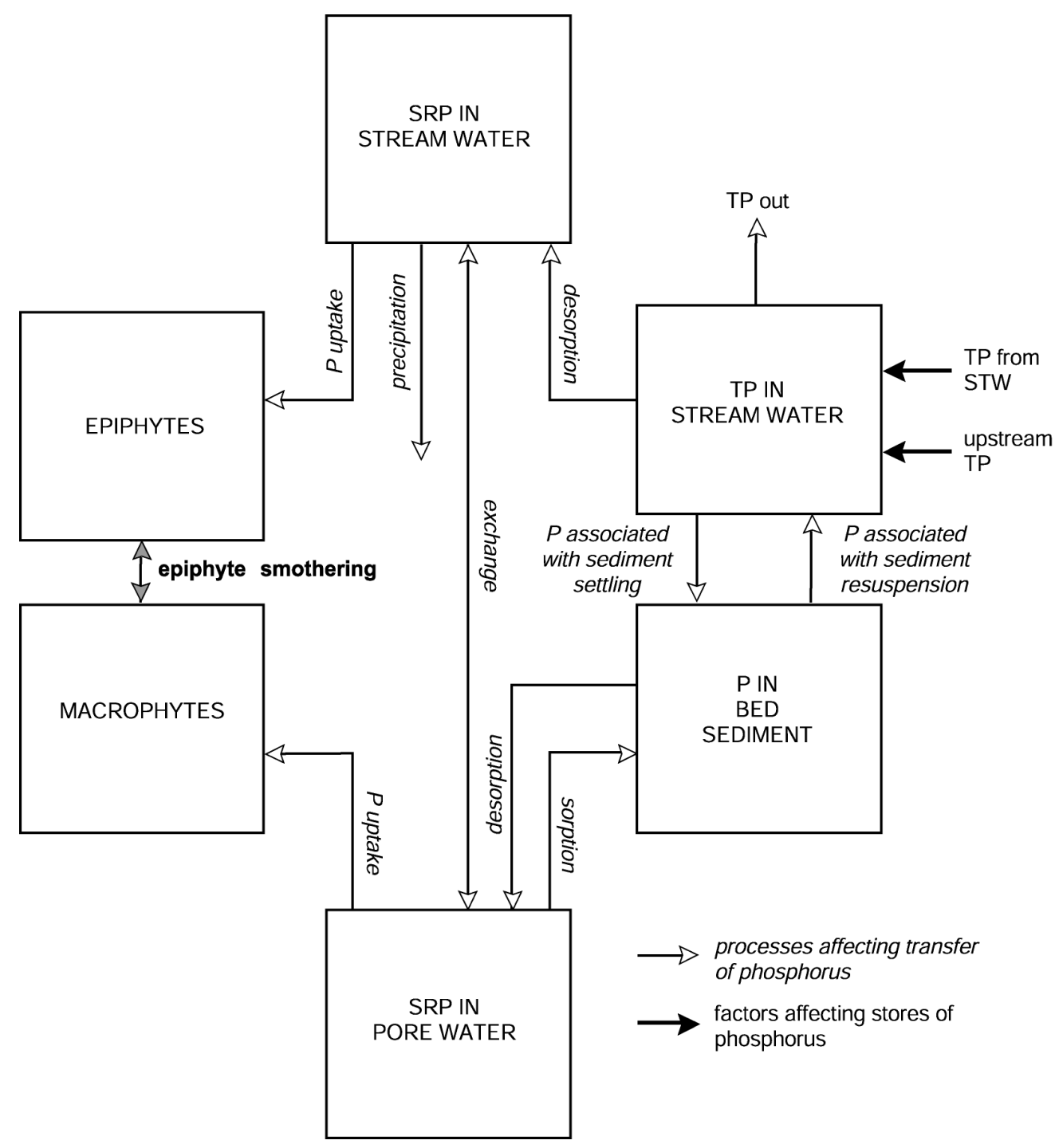

Fig. 3. Phosphorus inputs, processes and outputs in the in-stream components. 
Streamwater TP and SRP concentrations are simulated in this first instance because TP is a measure of the total amount of $\mathrm{P}$ in the system, and therefore is useful for mass balance, whilst SRP is a measure of the dissolved $\mathrm{P}$ in the streamwater that is biologically available. It is assumed that TP is the sum of $\mathrm{SRP}+\mathrm{PP}+\mathrm{SUP}$ where $\mathrm{PP}$ is the particulate phosphorus and SUP is the soluble unreactive phosphorus. Mass-balance equations are used to quantify the amount of $\mathrm{P}$ (and carbon in the case of the macrophytes and epiphytes, and chlorophyll ' $a$ ' in the case of algae) associated with the different stores in the aquatic P cycle (Eqns. 23-48). The rates of mass transfer between the stores are modelled as first-order (linear) exchanges and these rates are represented as parameters in the equations. However, whilst the equations comprise linear exchanges, the combined response of feedbacks and temperature dependencies ensures the response is non-linear. The inputs, outputs, parameters and variables are listed in Tables 6 to 9 and the equations to check the mass-balance are presented in Appendix B. The terms $P_{i n}, B_{i n}, S_{i n}, L_{i n}$ and $D_{i n}$ used in the following equations are defined in Appendix $C$.

If available, effluent time series describing the effluent flow $\left(\mathrm{m}^{3} \mathrm{~s}^{-1}\right)$, and TP $\left(\mathrm{mg} \mathrm{P}^{-1}\right)$ and boron $\left(\mathrm{mg} \mathrm{B}^{-1}\right)$ concentrations are used to describe the inputs from STWs entering each reach in the system. Alternatively, constant values for the effluent flow and TP and $\mathrm{B}$ concentrations can be used.

The changes in water storage in the reach are represented using a simple linear-reservoir routing method, modified to account for the lateral and STW flow inputs. The differential equation used to model the flow within the reach is

$$
\frac{d x_{25}}{d t}=\frac{\left(S_{4}+S_{5}+U_{7}-x_{25}\right)}{T_{4}}
$$

where $x_{25}=$ the flow out of the reach at time $t\left(\mathrm{~m}^{3} \mathrm{~s}^{-1}\right), S_{4}=$ the upstream flow into the reach at time $t\left(\mathrm{~m}^{3} \mathrm{~s}^{-1}\right), S_{5}=$ the lateral inflow into the reach at time, $t\left(\mathrm{~m}^{3} \mathrm{~s}^{-1}\right), U_{7}=$ the STW flow into the reach at time $t\left(\mathrm{~m}^{3} \mathrm{~s}^{-1}\right)$ and $T_{4}=$ the flow storage time constant (days) defined as

$$
T_{4}=\frac{L}{a x_{25}^{b} .86400}
$$

Thus, the time constant, $T_{4}$ is estimated from the reach length, $L$ divided by the flow velocity, $v$ which is itself estimated from the discharge using the expression $v=a x_{25}^{b}$, where $a$ and $b$ are constants. The values of $a$ and $b$ can be determined from flow-tracer experiments or from flowvelocity relationships derived at discharge gauging stations (Whitehead et al., 1979).

Given that $\mathrm{P}$ is attached to both the suspended and bed sediments, it is necessary to estimate the amount of sorption and desorption between the $\mathrm{P}$ in the water and that associated with the suspended and bed sediments (Fig. 3). To achieve this, an estimate of the mass of bed sediment is calculated from estimates of the reach length and width, and an estimate of the depth of the material that could potentially be resuspended. This bed mass is modified, at each time step, by an estimate of the amount of material re-suspended or deposited. This amount is determined from the change in grain size with flow: a cumulative frequency curve for bed sediment has been measured in the River Lambourn, S. England and, for a given grain size, the fraction of the bed that is held in suspension is estimated (Evans, 2002). The use of grain size data measured in the Lambourn is a starting strategy and, in the absence of similar data for other rivers, an assumption is made that the bed sediments of the Lambourn and other rivers are similar. This data extrapolation was made to permit the development of INCA$\mathrm{P}$ and further work will be necessary to determine the importance of this assumption when the model is applied to other river systems.

The equation for the change in mean grain diameter of the bed material suspended at time $t, x_{26}(\mu \mathrm{m})$ is

$$
\frac{d x_{26}}{d t}=C_{10}\left(\frac{S_{4}+S_{5}+U_{7}-x_{25}}{T_{4}}\right)
$$

where $C_{10}=$ a constant relating the flow in the reach to the mean grain diameter re-suspended or deposited from the overlying water column onto the stream bed $\left(\mu \mathrm{m} \mathrm{s} \mathrm{m}^{-3}\right)$. Whilst the change in grain diameter that is re-suspended or deposited is a function of the shear velocity and the channel roughness (Chow et al., 1988; Miller et al., 1977), a simple linear relationship between flow and grain diameter was used as a first approximation to limit the model's complexity. The change in grain size held in suspension was converted into a mass contribution to the suspended sediment mass at time $t, x_{27}(\mathrm{~kg})$ using the following equation

$$
\frac{d x_{27}}{d t}=\frac{d P M}{d x_{26}} \frac{d x_{26}}{d t}
$$

where $P M=$ the potentially movable bed mass $(\mathrm{kg})$, $x_{26}=$ the mean grain diameter of the bed material $(\mu \mathrm{m})$.

The change in the potentially available bed material with grain diameter is estimated as

$$
\frac{d P M}{d x_{26}}=\Delta C V \cdot x_{28} w L f
$$

where $\Delta C V$ is the slope of the curve relating the cumulative fraction of the bed material to the grain size $\left(\mu \mathrm{m}^{-1}\right), x_{28}$ is the total bed mass $\left(\mathrm{kg} \mathrm{m}^{-2}\right), f$ is the fraction of the total bed 
Table 6. Model parameters and output concentrations calculated within the in-stream phase of the INCA-P model.

\begin{tabular}{|c|c|c|}
\hline Symbol & Definition & Units \\
\hline $\mathrm{dx}_{25} / \mathrm{dt}$ & Change in the in-stream flow & $\mathrm{m}^{3} \mathrm{~s}^{-1} \mathrm{day}^{-1}$ \\
\hline $\mathrm{dx}_{26} / \mathrm{dt}$ & Change in the mean grain diameter & $\mathrm{kg}$ day $^{-1}$ \\
\hline $\mathrm{dx}_{27}^{20} / \mathrm{dt}$ & Change in the suspended sediment deposited or resuspended & $\mathrm{kg}$ day $^{-1}$ \\
\hline $\mathrm{dx}_{28} / \mathrm{dt}$ & Change in reach bed mass & $\mathrm{kg}_{\text {day }}{ }^{-1}$ \\
\hline $\mathrm{dx}_{29} / \mathrm{dt}$ & Change in suspended sediment stored in the reach & $\mathrm{kg}_{\text {day }}{ }^{-1}$ \\
\hline $\mathrm{dx}_{30} / \mathrm{dt}$ & Change in Boron stored in reach & $\mathrm{kg} \mathrm{B} \mathrm{day}^{-1}$ \\
\hline $\mathrm{dx}_{31} / \mathrm{dt}$ & Change in macrophyte biomass stored in water column in reach & $\mathrm{g} \mathrm{C}_{\text {day }}{ }^{-1} \mathrm{~m}^{-2}$ \\
\hline $\mathrm{dx}_{32} / \mathrm{dt}$ & Change in epiphyte biomass stored in water column in reach & $\mathrm{g} \mathrm{C}$ day $^{-1} \mathrm{~m}^{-2}$ \\
\hline $\mathrm{dx}_{33} / \mathrm{dt}$ & Change in Total Phosphorus stored in water column in reach & $\mathrm{kg} \mathrm{P}$ day $^{-1}$ \\
\hline $\mathrm{dx}_{34} / \mathrm{dt}$ & Change in Total Phosphorus stored in pore water in reach & $\mathrm{kg} \mathrm{P}$ day $^{-1}$ \\
\hline $\mathrm{dx}_{35} / \mathrm{dt}$ & Change in live algae stored in water column in reach & $\mu \mathrm{g} \mathrm{Chl} \mathrm{'a'} \mathrm{day}{ }^{-1}$ \\
\hline $\mathrm{dx}_{36} / \mathrm{dt}$ & Change in dead algae stored in water column in reach & $\mu \mathrm{g} \mathrm{Chl} \mathrm{'a'} \mathrm{day}{ }^{-1}$ \\
\hline $\mathrm{dx}_{37} / \mathrm{dt}$ & Change reach volume & $\mathrm{m}^{3}$ day $^{-1}$ \\
\hline $\mathrm{dx}_{38} / \mathrm{dt}$ & Change in flow volume into reach & $\mathrm{m}^{3}$ day $^{-1}$ \\
\hline $\mathrm{dx}_{39} / \mathrm{dt}$ & Change in flow volume out from reach & $\mathrm{m}^{3}$ day $^{-1}$ \\
\hline $\mathrm{dx}_{40} / \mathrm{dt}$ & Change in Total Phosphorus input to reach & $\mathrm{kg} \mathrm{P}_{\mathrm{day}}{ }^{-1}$ \\
\hline $\mathrm{dx}_{41} / \mathrm{dt}$ & Change in Total Phosphorus output from reach & $\mathrm{kg} \mathrm{P}_{\text {day }}{ }^{-1}$ \\
\hline $\mathrm{dx}_{42} / \mathrm{dt}$ & Change in epiphyte uptake in reach & $\mathrm{kg} \mathrm{P} \mathrm{day}^{-1}$ \\
\hline $\mathrm{dx}_{43} / \mathrm{dt}$ & Change in Total Phosphorus due to water column/pore water SRP exchange & $\mathrm{kg} \mathrm{P}_{\text {day }}{ }^{-1}$ \\
\hline $\mathrm{dx}_{44} / \mathrm{dt}$ & Change in Total Phosphorus co-precipitated with calcite & $\mathrm{kg} \mathrm{P}_{\text {day }}{ }^{-1}$ \\
\hline $\mathrm{dx}_{45} / \mathrm{dt}$ & Change in Total Phosphorus in water column due to PP re-suspension from bed & kg P day ${ }^{-1}$ \\
\hline $\mathrm{dx}_{46} / \mathrm{dt}$ & Change in Total Phosphorus in water column due to PP deposition on bed & $\mathrm{kg} \mathrm{P} \mathrm{day}^{-1}$ \\
\hline $\mathrm{x}_{25}$ & In-stream reach outflow & $\mathrm{m}^{3} \mathrm{~s}^{-1}$ \\
\hline$x_{26}$ & Mean grain diameter & $\mu \mathrm{m}$ \\
\hline$x_{27}$ & Suspended sediment deposited or resuspended & $\mathrm{kg}$ \\
\hline $\mathrm{x}_{28}$ & Reach bed mass & $\mathrm{kg} \mathrm{m}^{-2}$ \\
\hline$x_{29}$ & Suspended sediment stored in the reach & $\mathrm{kg}$ \\
\hline $\mathrm{x}_{30}$ & Boron stored in reach & $\mathrm{kg} \mathrm{B}$ \\
\hline$x_{31}$ & Macrophyte biomass stored in water column in reach & $\mathrm{g} \mathrm{C} \mathrm{m}^{-2}$ \\
\hline$x_{32}$ & Epiphyte biomass stored in water column in reach & $\mathrm{g} \mathrm{C} \mathrm{m}^{-2}$ \\
\hline$x_{33}$ & Total Phosphorus stored in water column in reach & $\operatorname{kg~P}$ \\
\hline$x_{34}$ & Total Phosphorus stored in pore water in reach & $\mathrm{kg} \mathrm{P}$ \\
\hline$x_{35}$ & Live algae stored in water column in reach & $\mu \mathrm{g}$ Chl 'a' \\
\hline$x_{36}$ & Dead algae stored in water column in reach & $\mu \mathrm{g} \mathrm{Chl} \mathrm{'a'}$ \\
\hline$x_{37}$ & Reach volume & $\mathrm{m}^{3}$ \\
\hline $\mathrm{x}_{38}$ & Flow volume into reach & $\mathrm{m}^{3}$ \\
\hline $\mathrm{x}_{39}$ & Flow volume out from reach & $\mathrm{m}^{3}$ \\
\hline $\mathrm{x}_{40}$ & Accumulated Total Phosphorus input to reach & $\mathrm{kg} \mathrm{P}$ \\
\hline $\mathrm{x}_{41}$ & Accumulated Total Phosphorus output from reach & $\mathrm{kg} P$ \\
\hline$x_{42}$ & Accumulated epiphyte uptake in reach & $\mathrm{kg} \mathrm{P}$ \\
\hline $\mathrm{x}_{43}$ & Accumulated Total Phosphorus due to water column/pore water SRP exchange & $\mathrm{kg} \mathrm{P}$ \\
\hline $\mathrm{x}_{44}$ & Accumulated Total Phosphorus co-precipitated with calcite & $\mathrm{kg} \mathrm{P}$ \\
\hline $\mathrm{x}_{45}$ & Accumulated Total Phosphorus in water column due to PP deposition on bed & $\mathrm{kg} \mathrm{P}$ \\
\hline$x_{46}$ & Accumulated Total Phosphorus in water column due to PP re-suspension from bed & $\mathrm{kg} \mathrm{P}$ \\
\hline
\end{tabular}


Table 7. Input time series, constants and time series calculated within the model.

\begin{tabular}{|c|c|c|}
\hline \multicolumn{2}{|c|}{ Input variable Description } & \multirow[t]{2}{*}{ Units } \\
\hline TIME S & & \\
\hline $\mathrm{U}_{7}$ & STW flow into reach at time, $\mathrm{t}$ & $\mathrm{m}^{3} \mathrm{~s}^{-1}$ \\
\hline $\mathrm{U}_{8}$ & Suspended sediment at time, $\mathrm{t}$ & $\operatorname{mg~Sed~} 1^{-1}$ \\
\hline $\mathrm{U}_{9}$ & Boron concentration in sewage effluent at time, $t$ & $\operatorname{mg~B~} 1^{-1}$ \\
\hline $\mathrm{U}_{10}$ & $\mathrm{TP}$ concentration in sewage effluent at time, $\mathrm{t}$ & $\mathrm{mg} \mathrm{P} \mathrm{l}^{-1}$ \\
\hline $\mathrm{U}_{11}$ & Solar Radiation at time, $\mathrm{t}$ & Normalised $0-1$ \\
\hline \multicolumn{3}{|c|}{ CONSTANTS } \\
\hline $\mathrm{L}$ & Reach length & $\mathrm{m}$ \\
\hline $\mathrm{w}$ & Reach width & $\mathrm{m}$ \\
\hline a & Velocity-discharge parameter & $\mathrm{m}^{-2}$ \\
\hline $\mathrm{b}$ & Velocity-discharge parameter & (Ø) \\
\hline DCV & Change in grain size suspended & $\mu \mathrm{m}^{-1}$ \\
\hline$f$ & Fraction of the total bed material that is available for resuspension & $(\varnothing)$ \\
\hline PM & Change in potentially moveable bed mass with respect to grain diameter & $\mathrm{kg}$ \\
\hline \multicolumn{3}{|c|}{ Calculated } \\
\hline $\mathrm{S}_{4}$ & Upstream flow into reach at time, $\mathrm{t}$ & $\mathrm{m}^{3} \mathrm{~s}^{-1}$ \\
\hline $\mathrm{S}_{5}$ & Lateral inflow into reach & $\mathrm{m}^{3} \mathrm{~s}^{-1}$ \\
\hline $\mathrm{S}_{6}$ & Upstream Total Phosphorus concentration at time, $\mathrm{t}$ & $\operatorname{mg~P~} 1^{-1}$ \\
\hline $\mathrm{S}_{7}$ & Upstream Boron concentration in water column at time, $\mathrm{t}$ & $\mathrm{mg} \mathrm{B} \mathrm{l}^{-1}$ \\
\hline $\mathrm{S}_{8}$ & Upstream concentration of live algae at time, $\mathrm{t}$ & $\mu \mathrm{g} \mathrm{Chl} \mathrm{'a'} \mathrm{l}^{-1}$ \\
\hline $\mathrm{S}_{9}$ & Upstream concentration of dead algae at time, $t$ & $\mu \mathrm{g} \mathrm{Chl} \mathrm{'a'} \mathrm{l}^{-1}$ \\
\hline $\mathrm{B}_{\text {in }}$ & Total Boron input to reach at time, $\mathrm{t}$ & $\mathrm{kg} \mathrm{B} \mathrm{day}^{-1}$ \\
\hline$P_{\text {in }}$ & Total Phosphorus input to reach at time, $\mathrm{t}$ & $\mathrm{kg} \mathrm{P}$ day $^{-1}$ \\
\hline$S_{\text {in }}$ & Suspended sediment input to reach at time, $t$ & $\mathrm{~kg}$ day $^{-1}$ \\
\hline $\mathrm{L}_{\mathrm{in}}$ & Live algae input to reach at time, $\mathrm{t}$ & $\mu \mathrm{g} \mathrm{Chl} \mathrm{'a'} \mathrm{day}{ }^{-1}$ \\
\hline $\mathrm{D}_{\text {in }}$ & Dead algae input to reach at time, $t$ & $\mu \mathrm{g} \mathrm{Chl} \mathrm{'a'} \mathrm{day}{ }^{-1}$ \\
\hline
\end{tabular}

material that is available for re-suspension (Ø) and $w$ is the reach width $(\mathrm{m})$.

The change in moveable bed mass at time $t, x_{28}\left(\mathrm{~kg} \mathrm{~m}^{-2}\right)$ is expressed using the following equation

$$
\frac{d x_{28}}{d t}=\frac{1}{L w} \frac{d x_{27}}{d t}
$$

where all the terms have been defined previously. The equation is an expression of the mass of sediment that is gained or lost from the bed following the re-suspension or deposition of sediment.

The in-stream suspended sediment concentration is assumed to depend on the material that enters the reach, plus or minus that material which is resuspended or deposited, respectively. When Eqn. (26) is negative then the grain size held in suspension falls and the term becomes negative, thereby allowing the simulation of deposition in Eqn. (29), which represents the suspended sediment, $x_{29}(\mathrm{~kg})$ in the reach

$$
\frac{d x_{29}}{d t}=S_{i n}-\frac{x_{29} x_{25} 86400}{x_{37}}+\frac{d x_{27}}{d t}
$$

where $S_{\text {in }}=$ the upstream suspended sediment mass at time, $t\left(\mathrm{~kg} \mathrm{day}^{-1}\right)$ and $x_{37}$ is the reach volume $\left(\mathrm{m}^{3}\right)$.

The equation for the change in the mass of Boron, $x_{30}(\mathrm{~kg}$ B) in the reach is

$$
\frac{d x_{30}}{d t}=B_{i n}-\frac{x_{30} x_{25} 86400}{x_{37}}
$$

where $B_{\text {in }}=$ the total mass of B entering the reach at time, $t$ $(\mathrm{kg} \mathrm{B})$ and $x_{30}=$ the B mass in the water column $(\mathrm{kg} \mathrm{B})$.

It is assumed that the B within the reach is entirely STW derived and there is no B in the lateral inflow (Neal et al., 2000). Boron is also assumed to be conservative; as such it does not take part in any reactions within the river reach and can be modelled using a simple input-output mass- 
Table 8. Model parameters.

\begin{tabular}{|c|c|c|c|c|}
\hline Parameter & Description & Units & $\begin{array}{l}\text { Value or range } \\
\text { given in or derived } \\
\text { from the literature }\end{array}$ & Reference \\
\hline $\mathrm{C}_{10}$ & Sediment resuspension/ settling & $\mu \mathrm{m} \mathrm{s} \mathrm{m}^{-3}$ & $1-10$ & Est. \\
\hline $\mathrm{C}_{11}$ & Macrophyte growth rate & day $^{-1}$ & $0.1-0.8$ & $\begin{array}{l}\text { Dawson, 1976; } \\
\text { Wright et al.,1982 }\end{array}$ \\
\hline $\mathrm{C}_{12}$ & Self-shading for macrophytes & $\mathrm{gC} \mathrm{m}^{-2}$ & 74 & Dawson, 1976 \\
\hline $\mathrm{C}_{13}$ & Half-saturation of $\mathrm{P}$ for macrophyte growth & $\operatorname{mg~P~} 1^{-1}$ & $0.0002-0.496$ & Bowie et al., 1985 \\
\hline $\mathrm{C}_{14}$ & Macrophyte death rate & $\mathrm{s} \mathrm{m}^{-1} \mathrm{~g} \mathrm{C}^{-1}$ day $^{-1}$ & $0.01-0.3$ & Chapra, 1997 \\
\hline $\mathrm{C}_{15}$ & Epiphyte growth rate & $\mathrm{m}^{2} \mathrm{~g} \mathrm{C}^{-1}$ day $^{-1}$ & $0.004-0.04$ & Chapra, 1997 \\
\hline $\mathrm{C}_{16}$ & Half-saturation of $\mathrm{P}$ for epiphyte growth & $\mathrm{mg} \mathrm{P} \mathrm{l}^{-1}$ & $0.0002-0.496$ & Bowie et al., 1985 \\
\hline$C_{17}^{10}$ & Epiphyte death rate & $\mathrm{s} \mathrm{m}^{-3}$ day $^{-1}$ & $0.01-0.05$ & Bowie et al., 1985 \\
\hline $\mathrm{C}_{18}$ & Proportion of $\mathrm{P}$ in epiphytes & $\mathrm{g} \mathrm{P} \mathrm{g}^{-1} \mathrm{C}$ & 0.0054 & Dawson, 1976 \\
\hline $\mathrm{C}_{19}$ & P exchange (water column $\backslash$ pore water) & $\mathrm{m}^{3}$ day $^{-1}$ & $0.4-86.4$ & $\begin{array}{l}\text { Wagner and } \\
\text { Harvey, } 1997\end{array}$ \\
\hline $\mathrm{C}_{20}$ & Precipitation of $\mathrm{P}$ in water column & $\mathrm{m}^{3}$ day $^{-1}$ & 0.68 & House et al., 1995 \\
\hline $\mathrm{C}_{21}$ & Bed (bulk) sediment depth & $\mathrm{m}$ & $0.1-1.0$ & Est. \\
\hline $\mathrm{C}_{22}$ & Proportion of $\mathrm{P}$ in macrophytes & $\mathrm{gP} \mathrm{g}^{-1} \mathrm{C}$ & 0.0054 & Dawson, 1976 \\
\hline $\mathrm{C}_{23}$ & Algal death rate & day $^{-1}$ & & \\
\hline $\mathrm{C}_{24}$ & Algal growth rate & day $^{-1}$ & & \\
\hline $\mathrm{C}_{25}$ & Half-saturation of $\mathrm{P}$ for algal growth & $\mathrm{mg} \mathrm{P} \mathrm{l}^{-1}$ & & \\
\hline $\mathrm{C}_{26}$ & Self-shading for algae & $\mu \mathrm{g} \mathrm{Chl} \mathrm{'a'} \mathrm{m-2}$ & & \\
\hline $\mathrm{C}_{27}$ & Settling rate of dead algae & day $^{-1}$ & & \\
\hline $\mathrm{C}_{28}$ & $\mathrm{~K}_{\mathrm{d}}^{\text {bed }}$ for bed sediment (as a fraction of $\mathrm{K}_{\mathrm{d}}^{\text {sus }}$ ) & $(\varnothing)$ & $0.1-1.0$ & Jarvie et al., 2002 \\
\hline $\mathrm{K}_{\mathrm{d}}^{\text {sus }}$ & $\mathrm{K}_{\mathrm{d}}^{\mathrm{a}}$ for suspended sediment & $\mathrm{dm}^{3} \mathrm{~kg}^{-1}$ & 200 & Jarvie et al., 2002 \\
\hline$\theta_{\mathrm{M}}$ & Macrophyte temperature dependency & $(\varnothing)$ & $1.01-1.066$ & Bowie et al., 1985 \\
\hline$\theta_{\mathrm{E}}$ & Epiphyte temperature dependency & $(\varnothing)$ & $1.01-1.066$ & Bowie et al., 1985 \\
\hline$\theta_{\mathrm{A}}$ & Algal temperature dependency & $(\varnothing)$ & $1.01-1.066$ & Bowie et al., 1985 \\
\hline $\mathrm{n}$ & Porosity & $(\varnothing)$ & 0.3 & Chow et al., 1988 \\
\hline$\rho_{\mathrm{s}}$ & Bulk sediment density & $\mathrm{kg} \mathrm{m}^{-3}$ & 2.65 & Chow et al., 1988 \\
\hline
\end{tabular}

Table 9. Output concentrations calculated within the in-stream phase of the INCA-P model.

\begin{tabular}{lll}
\hline Symbol & Definition & Units \\
\hline$a_{7}$ & Water column suspended sediment concentration & $\mathrm{mg} \mathrm{l}^{-1}$ \\
$a_{8}$ & Water column total phosphorus concentration & $\mathrm{mg} \mathrm{P} \mathrm{l}^{-1}$ \\
$a_{9}$ & Water column Boron concentration & $\mathrm{mg} \mathrm{B} \mathrm{l}^{-1}$ \\
$a_{10}$ & Pore water total phosphorus concentration & $\mathrm{mg} \mathrm{P} \mathrm{l}^{-1}$ \\
$a_{11}$ & Water column soluble reactive phosphorus concentration & $\mathrm{mg} \mathrm{P} \mathrm{l}^{-1}$ \\
$a_{12}$ & Pore water soluble reactive phosphorus concentration & $\mathrm{mg} \mathrm{P} \mathrm{l}^{-1}$ \\
$a_{13}$ & Water column live algae concentration & $\mu \mathrm{g} \mathrm{Chl} \mathrm{'a'} l^{-1}$ \\
$a_{14}$ & Water column dead algae concentration & $\mu \mathrm{g} \mathrm{Chl} \mathrm{'a} \mathrm{l}^{-1}$ \\
\hline
\end{tabular}


balance equation.

The differential equation used to model the change in the macrophyte biomass, $x_{31}\left(\mathrm{~g} \mathrm{C} \mathrm{m}^{-2}\right)$ flow within the reach is

$$
\frac{d x_{31}}{d t}=\frac{C_{11} \theta_{M}^{\left(U_{4}-20\right)} x_{31} U_{11} C_{12} a_{12}}{\left(C_{13}+a_{12}\right)\left(C_{12}+x_{31}\right)}-C_{14} x_{32} x_{31} x_{25}
$$

where

$\theta_{M}=$ macrophyte temperature dependency (Ø),

$C_{11}=$ the macrophyte growth rate $\left(\right.$ day $\left.^{-1}\right)$,

$C_{12}=$ the constant associated with macrophyte self-shading $\left(\mathrm{g} \mathrm{C} \mathrm{m}^{-2}\right.$ ),

$C_{13}=$ the half saturation constant associated with the macrophyte growth $\left(\mathrm{mg} \mathrm{P}^{-1}\right)$,

$C_{14}=$ the macrophyte death rate $\left(\mathrm{s} \mathrm{m}^{-1} \mathrm{~g} \mathrm{C}^{-1}\right.$ day $\left.{ }^{-1}\right)$,

$U_{11}=$ solar radiation,

$a_{12}=$ the pore water SRP concentration $\left(\mathrm{mg} \mathrm{P}^{-1}\right)$ and

$U_{4}=$ water temperature $\left({ }^{\circ} \mathrm{C}\right)$.

The general form of Eqn. (31), which simulates the interactions between the macrophytes and the epiphytic algae, is based on the Lotka-Volterra model of predatorprey interactions (Lotka, 1926; Volterra, 1926). In this case, the macrophytes are considered as the "prey" and the epiphytic algae as the "predator". Whilst the coexistence of macrophytes and epiphytes is not a true predator-prey relationship, the Lotka-Volterra model does generate the expected relational changes in biomass. Unmodified formulations of the original Lotka-Volterra predation model produce peak biomass estimates that are mainly dependent on the initial conditions (Hastings, 1997). As such, the basic Lotka-Volterra model has been modified as follows. The first order growth rate, $C_{11}$ is dependent upon the substrate (pore water) SRP concentration (Thornley, 1976). This dependency is described by the Michaelis-Menten formulation, in which the half-saturation constant, $C_{13}$ represents the substrate concentration at which growth is half the maximum. As such, the parameter, $C_{13}$ dictates at what level the substrate becomes limiting. The term for the macrophyte growth also is modified to account for the seasonal variations in solar radiation and water temperature. The second term, which includes the product of the macrophyte and epiphyte biomass, $x_{32} x_{31}$, on the right hand side of Eqn. (31) quantifies the effect the impact of the epiphytic algae has on the macrophyte mortality. This term is also flow dependent to account for the wash out of macrophytes from the reach under high flow conditions.

The change in epiphyte biomass stored in reach at time $t$, $x_{32}\left(\mathrm{~g} \mathrm{C} \mathrm{m}^{-2}\right)$ is represented by the following equation

$$
\frac{d x_{32}}{d t}=\frac{C_{15} \theta_{E}^{\left(U_{4}-20\right)} x_{32} x_{31} U_{11} a_{11}}{C_{16}+a_{11}}-C_{17} x_{32} x_{25}
$$

where

$\theta_{E}=$ epiphyte temperature dependency $(\varnothing)$,

$C_{15}=$ the epiphyte growth rate $\left(\mathrm{m}^{2} \mathrm{~g} \mathrm{C}^{-1}\right.$ day $\left.^{-1}\right)$,

$C_{16}=$ the half saturation constant associated with the epiphyte growth $\left(\mathrm{mg} \mathrm{P} \mathrm{L}^{-1}\right)$,

$C_{17}=$ the epiphyte death rate $\left(\mathrm{s} \mathrm{m}^{-3}\right.$ day $\left.^{-1}\right)$ and

$a_{11}$ is the water column SRP concentration $\left(\mathrm{mg} \mathrm{P}^{-1}\right)$.

The term $\frac{C_{15} \theta_{E}{ }^{(T-20)} U_{11} a_{11}}{C_{16}+a_{11}}$ from Eqn. (32) quantifies the epiphyte growth. As in the case of the macrophytes, it is based on the Michaelis-Menten formulation but with a dependency upon the SRP available in the water column in addition to the water temperature and the solar radiation. The death rate of the epiphytes is also flow dependent.

The change in the TP in the water column at time $t, x_{33}(\mathrm{~kg}$ $\mathrm{P}$ ) is represented by the following equations

$$
\begin{array}{r}
\frac{d x_{33}}{d t}=P_{\text {in }}-\frac{x_{33} x_{25} 86400}{x_{37}}-\frac{C_{18} C_{15} \theta_{E}^{\left(U_{4}-20\right)} x_{32} x_{31} U_{11} a_{11} L w}{\left(C_{16}+a_{11}\right) \cdot 1000}+ \\
\frac{C_{19}}{1000}\left(a_{12}-a_{11}\right)-\frac{C_{20}}{1000} a_{11}+\left\{\begin{array}{l}
\text { gain } \\
\text { loss }
\end{array}\right\}
\end{array}
$$

where gain $=\frac{1}{\rho_{s}(1-n) w L C_{21}} x_{34} \frac{d x_{27}}{d t}$, if $\frac{d x_{27}}{d t}>0$

and loss $=10^{-6} a_{11} K_{D}^{S U S} \frac{d x_{27}}{d t}$, if $\frac{d x_{27}}{d t} \leq 0$

where

$P_{i n}=$ the total mass of $\mathrm{P}$ entering the reach at time,

$t(\mathrm{~kg} \mathrm{P})$,

$C_{18}=$ the ratio of phosphorus to carbon in epiphytes

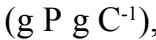

$C_{19}=$ the constant associated with the exchange of SRP between the pore water and the overlying water column $\left(\mathrm{m}^{3}\right.$ day $\left.^{-1}\right)$,

$C_{20}=$ the constant associated with the co-precipitation of $\mathrm{P}$ with calcite in the water column $\left(\mathrm{m}^{3}\right.$ day $\left.^{-1}\right)$,

$C_{21}=$ the bulk sediment depth (m),

$x_{34}=$ the TP mass associated with the bed sediment (kg P),

$K_{D}^{\text {Sus }}=\mathrm{K}_{\mathrm{d}}$ for suspended sediment $\left(\mathrm{dm}^{3} \mathrm{~kg}^{-1}\right)$,

$K_{D}^{B e d}=\mathrm{K}_{\mathrm{d}}$ for bed sediment $\left(\mathrm{dm}^{3} \mathrm{~kg}^{-1}\right)$,

$n=$ the porosity $(\varnothing)$,

$r_{s}=$ the bed sediment bulk density $\left(\mathrm{kg} \mathrm{m}^{-3}\right)$.

The $K_{d}$ values are a measure of the affinity of the solid phase for sorbing P from the surrounding substrate (House et al., 1995; House and Warwick, 1999). 
It is assumed that the TP concentration of the water column is determined by the amount of phosphorus entering the reach (from both upstream and the STW), epiphyte uptake, sorption/desorption of $\mathrm{P}$ to and from the suspended sediment, exchange of $\mathrm{P}$ between the pore water and water column and the precipitation of P (Fig. 3). As such, the estimate of the change in the TP concentration is based only on changes in the PP and SRP: it is assumed that any SUP present, by definition, does not take part in any reactions.

The TP concentration input to the reach is calculated from the mass balance of all the known P sources: upstream, STW and lateral flow inputs. The first and second terms on the right hand side of Eqn. (33) represent the input and output of TP to and from the reach, respectively. The third term represents the uptake of SRP by the epiphytic algae. As such, the term is described in more detail with reference to epiphyte biomass Eqn. (32). The fourth term on the right hand side of Eqn. (33) represents the exchange of SRP between the pore water and the overlying water column. When the pore water concentration is greater than that of the overlying water column then there is a net transfer of SRP to the overlying water column. Conversely, if the SRP concentration is greater in the overlying water column compared to the pore water, then SRP is transferred to the pore water. The fifth term represents the loss of SRP from the water column by co-precipitation with calcite. The final term represents the loss of total phosphorus from the water column to the stream bed by sediment deposition or the gain of PP from the bed during periods of resuspension. Given $\frac{d x_{27}}{d t}$ can be both positive and negative, then the sign represents the addition or subtraction of PP from the TP store in the water column. It is assumed that PP in suspension in the water column is in equilibrium with the surrounding SRP in the water column and that the PP associated with the stream bed is in equilibrium with the surrounding SRP in the pore water. The gain and loss terms reflect these equilibrium conditions, which are expressed in terms of $K_{d}$ values. It is assumed that $K_{D}^{\text {Bed }} \leq K_{D}^{\text {Sus }}$, since the sediment in suspension will sorb more SRP than the bed sediment. For the purposes of estimating suitable values for $K_{D}^{B e d}$ and $K_{D}^{\text {Sus }}$ both are assumed to lie in the range 100 to $300 \mathrm{dm}^{3}$ $\mathrm{kg}^{-1}$, which is the range specified for bed sediment by Jarvie et al., (2002). As such, $K_{D}^{\text {Sus }}$ is chosen from this range and $K_{D}^{\text {Bed }}$ is estimated as a fraction, $C_{28}(0.1$ to 1.0$)$ of $K_{D}^{\text {Sus }}$

$$
K_{D}^{\text {Bed }}=C_{28} K_{D}^{\text {Sus }}
$$

The equation for the change in the TP associated with the river bed, $x_{34}(\mathrm{~kg} \mathrm{P})$ in the reach is

$$
\begin{array}{r}
\frac{d x_{34}}{d t}=-\left\{\begin{array}{l}
\text { gain } \\
\text { loss }
\end{array}\right\}-\frac{C_{19}}{1000}\left(a_{12}-a_{11}\right)- \\
\frac{C_{22} C_{11} \theta_{M}{ }^{\left(U_{4}-20\right)} x_{31} U_{11} C_{12} a_{12} L w}{\left(C_{13}+a_{12}\right)\left(C_{12}+x_{31}\right) 1000}
\end{array}
$$

where loss $=\frac{1}{\rho_{s}(1-n) w L C_{21}} x_{34} \frac{d x_{27}}{d t}$, if $\frac{d x_{27}}{d t}>0$

and gain $=10^{-6} a_{11} K_{D}^{\text {SUS }} \frac{d x_{27}}{d t}$, if $\frac{d x_{27}}{d t} \leq 0$

where $C_{22}=$ the ratio of phosphorus to carbon in macrophytes ( $\mathrm{g} \mathrm{P} \mathrm{g} \mathrm{C}^{-1}$ ).

It is assumed that the TP associated with the river bed is affected by three factors.

- The mass of phosphorus sorbed on the bed sediment. As such, the gain and loss term on the right hand side of Eqn. (37) represents the movement of PP between the stream bed and the overlying water column due to deposition (a gain of PP to the stream bed) and resuspension (a loss of PP from the stream bed).

- The interaction between the SRP associated with the pore water and the overlying water column. The conversion ratio of $\mathrm{P}: \mathrm{C}$ relates the mass of $\mathrm{P}$ removed from the pore water to the changes in macrophyte biomass, which is measured in terms of carbon (Dawson, 1976).

- The uptake of SRP from the pore water during periods of macrophyte growth.

The pore water depth, $p$ cannot be greater than the bulk sediment depth. As such, the pore water depth is estimated as a fraction, $n$ of the bulk sediment depth, $C_{21}$. The fraction equates to the porosity, namely,

$$
p=n C_{21}
$$

The equations for the change in live and dead biomass of algae within the reach are those developed by Whitehead and Hornberger (1984). The change in live algae stored in the water column of the reach, $x_{35}$ ( $\mu \mathrm{g} \mathrm{Chl} \mathrm{'a')} \mathrm{is} \mathrm{given} \mathrm{by}$

$$
\begin{array}{r}
\frac{d x_{35}}{d t}=L_{\text {in }}-\frac{x_{35} x_{25} 86400}{x_{37}}-C_{23} x_{35}+ \\
C_{24} x_{35} \theta_{A}^{\left(U_{4}-20\right)} U_{11}\left(\frac{a_{11}}{a_{11}+C_{25}}\right)\left(\frac{C_{26}}{C_{26}+x_{35}}\right)
\end{array}
$$

and the change in dead algae stored in the water column of the reach , $x_{36}(\mu \mathrm{g} \mathrm{Chl} \mathrm{'} \mathrm{a}$ ') is estimated as 
$\frac{d x_{36}}{d t}=D_{i n}-\frac{x_{36} x_{25} 86400}{x_{37}}+C_{23} x_{35}-C_{27} x_{36}$

where

$L_{i n}$ and $D_{i n}$ are the masses of live and dead algae input to the reach from the upstream flow,

$\theta_{A}=$ algal temperature dependency $(\varnothing)$,

$C_{23}=$ the algal death rate $\left(\right.$ day $\left.^{-1}\right)$,

$C_{24}=$ algal growth rate $\left(\right.$ day $\left.^{-1}\right)$,

$C_{25}=$ the $\mathrm{P}$ half-saturation for algal growth $\left(\mathrm{mg} \mathrm{P}^{-1}\right)$,

$C_{26}=$ the self-shading factor $\left(\mu \mathrm{g} \mathrm{Chl} \mathrm{'} \mathrm{a}\right.$ ' $\left.\mathrm{m}^{-2}\right)$ and

$C_{27}=$ the settling rate for dead algae $\left(\right.$ day $\left.^{-1}\right)$.

\section{Calculation of concentrations}

The concentrations of suspended sediment, B, water column and pore water TP are calculated as the load divided by the volume of the store. For example, for water column TP, $a_{8}\left(\mathrm{mg} \mathrm{P} \mathrm{1}^{-1}\right)$ :

$$
a_{8}=\frac{x_{33} \cdot 1000}{x_{37}}
$$

Based on data gathered in the River Lambourn, it is assumed that $25 \%$ of TP is SUP (Prior, 1998). Whilst this percentage is known to change with the prevailing flow conditions, the assumption was made so that SUP concentration data (which are generally unavailable) are not required to apply the model, whereas TP and SRP data tend to be collected by the Environment Agency at routine monitoring sites throughout England and Wales. Thus,

$$
T P=P P+S R P+0.25 T P
$$

Substitute $P P=S R P \cdot 10^{-6} K_{D}^{\text {Sus }} a_{7}$ into Eqn. (44) and rearrange to give the following expression for the water column SRP concentration, $a_{11}\left(\mathrm{mg} \mathrm{P}^{-1}\right)$, where $T P=$ water column TP concentration, $a_{8}\left(\mathrm{mg} \mathrm{P}^{-1}\right)$ and $a_{7}=$ the water column suspended sediment concentration $\left(\mathrm{mg} \mathrm{l}^{-1}\right)$ :

$$
a_{11}=\frac{0.75 a_{8}}{1+10^{-6} K_{D}^{\text {Sus }} a_{7}}
$$

By the same arguments used to derive Eqn. (45), the equation for the change in the SRP pore water concentration, $a_{12}$ $\left(\mathrm{mg} \mathrm{Pl}^{-1}\right)$ in the reach is

$$
a_{12}=\frac{0.75 a_{10}}{1+\frac{10^{-3} K_{D}^{\text {Bed }} x_{28}}{n C_{21}}}
$$

where $P P=a_{12} \frac{K_{D}^{B e d}}{n C_{21}} 10^{-3} x_{28}$ in this case and $a_{10}=$ pore water TP concentration ( $\mathrm{mg} \mathrm{P} \mathrm{l}^{-1}$ ). If SUP (or the equivalent dissolved hydrolysable P, DHP) concentration data are available, then the values could be substituted in Eqn. (44). The concentration of live algae, $a_{13}\left(\mu \mathrm{g} \mathrm{Chl} \mathrm{'a'} \mathrm{l}^{-1}\right)$ in the water column is given by:

$$
a_{13}=\frac{x_{35}}{x_{37} \cdot 1000}
$$

and the concentration of dead algae, $a_{14}\left(\mu \mathrm{g} \mathrm{Chl} \mathrm{'a'} \mathrm{l}^{-1}\right)$ in the water column by:

$$
a_{14}=\frac{x_{36}}{x_{37} \cdot 1000}
$$

\section{Discussion and conclusions}

INCA-P attempts to model all the key processes affecting the transport and retention of $\mathrm{P}$ within a river system. As the model is based on mass-balance, it is applicable at a broad range of spatial and temporal scales. When coupled with high quality data, the model provides:

- A methodology for formalising the concepts and assumptions relating to the behaviour of $\mathrm{P}$ within the plant/soil and in-stream systems.

- A methodology for testing hypothesies regarding different processes.

- A learning tool for examining the dynamics of water quality both in terms of spatial variations in highly heterogeneous systems and daily flow events and longterm changes in catchment $\mathrm{P}$ stores.

Thus, INCA-P represents a significant step towards a complete model of $\mathrm{P}$ and biological dynamics. The model is transparent, providing estimates of both annual and daily $P$ fluxes, soil and streamwater $\mathrm{P}$ concentrations and the impacts on the biological biomass. However model applications, covering a broad range of $\mathrm{P}$ issues and plot and catchment types are required to build confidence in the model's ability to simulate $\mathrm{P}$ dynamics and the associated biological response. Since the model is based on the same hydrological, land use and land management data used in INCA, which has been applied to many catchments throughout the UK and Europe, then it is assumed that INCA-P can be applied to a similar, broad range of catchments to gain knowledge regarding its utility as a modelling tool (Wade et al., 2002b).

Since INCA-P is semi-distributed then it is impossible to simulate the small-scale transport of $\mathrm{P}$ across the land 
surface, and therefore locate any P 'hot spots' or wedges of $P$ stores at scales measured at less than approximately $1 \mathrm{~km}^{2}$. Furthermore, the representation of the $\mathrm{P}$ soil processes does not account for soil type, microbe species, and the in-stream model does not include any mechanism to simulate macrophyte species competition, or cutting. Clearly, many of the assumptions made in the creation of INCA-P are simplifications of reality and it is possible that, without simulating the detailed small-scale processes, the necessary feed-forward and feed-back processes are missing, and therefore any model predictions must remain tentative until validated by observation. Given the problems of structural, parameter and data uncertainty, the adequacy of processbased models, such as INCA-P, to represent the relative importance of the different internal catchment processes and the rate at which they operate remains uncertain. This is especially important when considering the response of such processes to environmental change, when such models are applied outside the data against which they were calibrated. Despite this, INCA-P and similar process-based waterquality models still provide tools with which to test ideas regarding hydrochemical dynamics within river catchments.

A pragmatic approach to overcome the current limitations of models could be achieved through the use of modelling frameworks, whereby a suite of data analysis tools and modelling approaches is used to determine the likely changes in the water quality at different spatial and temporal scales in response to environmental perturbations (Wade, 1999). Recent data analysis and modelling work suggest that at large spatial $\left(>100 \mathrm{~km}^{2}\right)$ scales, key geographical properties can be used to simulate the spatial variations in streamwater solute concentrations, though at small scales detailed data are required to understand the mechanisms operating. Furthermore, these studies also note that dynamic, processbased models are required to assess the temporal variations in water quality. Thus, modelling techniques based entirely on emergent properties, whilst appealing because of their simplicity, have limited use for assessing the impacts of environmental change because they do not simulate such processes. Consequently, dynamic models such as INCA-P are necessary. Whilst the model is based on land use, which is the key characteristic in determining the spatial variations in streamwater $\mathrm{P}$ concentrations, it also includes a representation of $\mathrm{P}$ exchange kinetics and retention. As such, INCA-P could be used to investigate the first-order impacts, and more detailed models, or expert opinion used to infer the likely second-order effects at the smaller spatial and temporal scales. In addition, linking INCA-P with INCA could provide a more complete assessment of the combined impacts of $\mathrm{N}$ and $\mathrm{P}$ in river systems, especially in situations where a system was alternately $\mathrm{N}$ and $\mathrm{P}$ limited. This, together with further applications of INCA-P to different catchments, will be the main goal of future work.

\section{Acknowledgements}

This research has drawn together work funded by the Natural Environment Research Council and the Environment Agency. The authors would like to thank Heather Browning for help with the diagrams and Colin Neal for the constructive criticism of early drafts.

\section{References}

Abbot, M.B., Bathurst, J.C., Cunge, J.A., O'Connell, P.E. and Rosmussen, J., 1986. An introduction to the Système Hydrologique Européen (SHE). J. Hydrol., 87, 45-77.

Barr, C.J., Bunce, R.G.H. and Clarke, R.T., 1993. Countryside Survey 1990. Main Report. Report to the Department of the Environment. Institute of Terrestrial Ecology and the Institute of Freshwater Ecology.

Bowie, G.L., Mills, W.B., Porcella, D.B., Campbell, C.L., Pagenkopf, J.R., Rupp, G.L., Johnson, K.M., Chan, W.H. and Gherini, S.A., 1985. Rates, Constants and Kinetics Formulations in Surface Water Quality Modeling (Second Edition). Environmental Research Laboratory, US Environmental Protection Agency, Athens, Georgia (EPA/600/3-85/040).455pp.

Chapra, S., 1997. Surface water quality modeling. McGraw-Hill Inc., New York. 622-632.

Chow, V.T., Maidment, D.R. and Mays, L.W. (Eds.), 1988. Handbook of Applied Hydrology. McGraw-Hill Inc. New York. 33-40.

Dawson, F.H., 1976. The annual production of the aquatic macrophyte Ranunculus penicillatus var. calcareous (R.W. Butcher) C.D.K. Cook. Aquatic Botany, 9, 145-152.

European Commission (EC)., 2000. Directive 2000/60/EC 2000 of the European Parliament and of the Council of the 23 October 2000 establishing a framework for Community action in the field of water policy. Official Journal of the European Communities.

Evans, D., 2002. Phosphorus transport and transformation dynamics in lowland streams. Unpublished $\mathrm{PhD}$ Thesis, University of Reading, UK.

Fertiliser Manufacturers' Association, 1994. British Survey of Fertiliser Practice: Fertiliser use on Farm Crops. HMSO, London.

Gburek, W.J. and Sharpley, A.N., 1998. Hydrological Controls on Phosphorus Loss from Upland Agricultural Watersheds. $J$. Environ. Qual., 27, 267-277.

Green, F.H. and Harding, R.J., 1979. Altitudinal gradients of soil temperature in Europe. Inst. Br. Geogr., 5, 248-315.

Groenendyk, P. and Kroes, J.G., 1999. Modelling the nitrogen and phosphorus leaching to groundwater and surface water with ANIMO 3.5. Report 144. The Winand Staring Center, Wageningen, The Netherlands. 138 pp.

Gustard, A., Marhsall, D.C.W. and Sutcliffe, M.F., 1987. Low flow estimation in Scotland. Institute of Hydrology Report 101, Institute of Hydrology, Wallingford, UK.

Hall, R.L. and Harding, R.J., 1993 The water use of the Balquhidder catchments: a process approach. J. Hydrol., 145, 285-315. 
Hastings, A., 1997. Population Biology: concepts and models. Springer, New York. 119-180.

Hough, M., Palmer, S., Weir, A., Lee, M. and Barrie, I., 1997. The Meteorological Office Rainfall and Evaporation Calculation System: MORECS Version 2.0 (1995). An update to Hydrological Memorandum 45. Meteorological Office, Bracknell.80 pp.

House, W.A. and Warwick, M.S., 1999. Interactions of phosphorus with sediments in the River Swale, Yorkshire, UK. Hydrol. Process., 13, 1103-1115.

House, W.A., Denison, F.H. and Armitage, P.D., 1995. Comparison of the uptake of phosphorus to a suspended and stream bedsediment. Water Res., 29, 767-779.

Jarvie, H.P., Neal, C., Williams, R.J., Tagg, A., Neal, M., Wickham, H.D., Hill, L.K., Wade, A.J., Warwick, A. and White, J., 2002. Phosphorus sources, speciation and dynamics in a lowland eutrophic Chalk river: the River Kennet, UK. Sci. Total Envir, 282/283, 175-203.

Kao, J.-J., Lin, W.-L. and Tsai, C.-H., 1998. Dynamic spatial modelling approach for estimation of internal phosphorus load. Water Res., 32, 47-56.

Lotka, A.J., 1926. Elements of Physical Biology. Williams and Wilkins, Baltimore, USA.

Mainstone, C.P., Parr, W. and Day, M., 2000. Phosphorus and River Ecology: tackling sewage inputs. English Nature, Peterborough, UK. 1-46.

Marsh, T.J. and Sanderson, F.J., 1997. A review of hydrological conditions throughout the LOIS monitoring programme considered within the context of the recent UK climate volatility. Sci. Total Envir., 194/195, 59-70.

Miller, M .C., McCave, I.N. and Komar, P.D., 1977. Threshold of sediment motion under unidirectional currents. Sedimentology, 24, 507-527.

Morris, D.G. and Flavin, R.W., 1994. Sub-set of the UK $50 \mathrm{~m}$ by $50 \mathrm{~m}$ hydrological digital terrain model grids. NERC. Institute of Hydrology, Wallingford, UK.

Neal, C., 1997. A view of water quality from the Plynlimon watershed. Hydrol. Earth Syst. Sci., 3, 743-753.

Neal, C., Jarvie, H.P., Howarth, S.M., Whitehead, P.G., Williams, R.J., Neal, M., Harrow, M. and Wickham, H., 2000. The water quality of the River Kennet: initial observations on a lowland chalk stream impacted by sewage inputs and phosphorus remediation. Sci. Total Envir. 251/252, 477-495.

Prior, H., 1998. Total nitrogen and total phosphorus cycling in riparian ecosystems. Unpublished $\mathrm{PhD}$ Thesis, University of Reading, UK.

Thornley, J.H.M., 1976. Mathematical models in Plant Physiology: A quantitative approach to problems in plant and crop physiology. Academic Press, London. 8-15.

\section{Appendix A}

\section{LAND PHASE MASS-BALANCE CHECK}

Accumulated total organic $\mathrm{P}$ mass associated with input to the cell, $x_{12}\left(\mathrm{~kg} \mathrm{P} \mathrm{km}^{-2}\right)$, is calculated from integrating the change in total organic phosphorus mass input, $d x_{12} / d t$

$$
\frac{d x_{12}}{d t}=U_{2} .100
$$

Accumulated total organic P mass associated with output
Vollenweider, R.A., 1975. Input-output models with special reference to the phosphorus loading concept in limnology. Schweiz. Z. Hydrol., 37, 53-84.

Volterra, V., 1926. Fluctuations in the abundance of a species considered mathematically. Nature, 118, 558-560.

Wade, A.J., 1999. Assessment and modelling of water chemistry in a large catchment: River Dee, NE. Scotland. Unpublished $\mathrm{PhD}$ Thesis, Aberdeen University.

Wade, A.J., Neal, C., Soulsby, C., Langan, S.J. and Smart, R.P., 2001. On modelling the effects of afforestation on acidification in heterogeneous catchments at different spatial and temporal scales. J. Hydrol., 250, 149-169.

Wade, A.J., Hornberger, G.M., Whitehead, P.G., Jarvie, H.P. and Flynn, F., 2002a. On modelling the mechanisms that control instream phosphorus, macrophyte and epiphyte dynamics: an assessment of a new model using General Sensitivity Analysis. Water Resour. Res., 37, 2777-2792.

Wade, A.J., Durand, P., Beaujouan, V., Wessel, W.W., Raat, K.J., Whitehead, P. G., Butterfield, D., Rankinen, K. and Lepisto, A., 2002b. A nitrogen model for European catchments: INCA, new model structure and equations. Hydrol. Earth Syst. Sci., 6, 559-582.

Wade, A.J., Whitehead, P.G., Hornberger, G.M., Jarvie, H.P. and Flynn. N., 2002c. On modelling the impacts of sewage works on in-stream phosphorus and macrophyte/epiphyte dynamics: a case study of the river Kennet. Sci. Total Environ., 282/283, 395-415.

Wagner, B.J. and Harvey, J.W., 1997. Experimental design for estimating parameters of rate-limited mass transfer: analysis of stream tracer studies. Water Resour. Res., 33, 1731-1741.

Whitehead, P.G. and Hornberger, G.M., 1984. Modelling algal behaviour in the River Thames. Water Res., 18, 945-953.

Whitehead, P.G., Young, P.C. and Hornberger, G.M., 1979. A systems model of stream flow and water quality in the BedfordOuse River Part 1, stream flow modelling. Water Res., 6, 11551169.

Whitehead, P.G., Wilson, E.J. and Butterfield, D., 1998a. A semidistributed nitrogen model for multiple source assessments in catchments (INCA): Part 1 - model structure and process e quations. Sci. Total Envir., 210/211, 547-558.

Whitehead, P.G., Wilson, E.J., Butterfield, D. and Seed, K., 1998b. A semi-distributed integrated flow and nitrogen model for multiple source assessment in catchments (INCA): Part II application to large river basins in South Wales and eastern England. Sci. Total Envir., 210/211, 559-583.

Wright, J.F., Cameron, C., Hiley, P.D. and Berrie, A.D., 1982. Seasonal changes in biomass of macrophytes on shaded and unshaded sections of the River Lambourn, England. Freshwater Biol., 12, 271-283. from the cell, $x_{13}\left(\mathrm{~kg} \mathrm{P} \mathrm{km}^{-2}\right)$, is calculated from integrating the change in total organic phosphorus mass output, $d x_{13} / d t$

$$
\begin{aligned}
& \frac{d x_{13}}{d t}=\frac{(1-\alpha-\beta) x_{2} x_{4} \cdot 86400}{V_{r}+x_{16}}+ \\
& \frac{x_{3} x_{6} \cdot 86400}{x_{17}}+\frac{x_{1} x_{8} \cdot 86400}{x_{18}}
\end{aligned}
$$

Accumulated total inorganic $\mathrm{P}$ mass associated with input to the cell, $x_{14}\left(\mathrm{~kg} \mathrm{P} \mathrm{km}^{-2}\right)$, is calculated from integrating the 
change in total inorganic phosphorus mass input, $d x_{14} / d t$

$$
\frac{d x_{14}}{d t}=U_{3} .100
$$

Accumulated total inorganic $\mathrm{P}$ mass associated with output from the cell, $x_{15}\left(\mathrm{~kg} \mathrm{P} \mathrm{km}^{-2}\right)$, is calculated from integrating the change in total inorganic phosphorus mass output, $d x_{15}$ / $d t$

$$
\begin{aligned}
\frac{d x_{15}}{d t}=\frac{(1-\alpha-\beta) x_{2} x_{5} .86400}{V_{r}+x_{16}}+ \\
\frac{x_{3} x_{7} .86400}{x_{17}}+\frac{x_{1} x_{9} .86400}{x_{18}}
\end{aligned}
$$

Accumulated soil water drainage volume, $x_{16}\left(\mathrm{~m}^{3} \mathrm{~km}^{-2}\right)$, is calculated from integrating the change in the soil water drainage volume, $d x_{16} / d t$

$$
\frac{d x_{16}}{d t}=\left(U_{1}-x_{2}\right) \cdot 86400
$$

Accumulated groundwater drainage volume, $x_{17}$ $\left(\mathrm{m}^{3} \mathrm{~km}^{-2}\right)$, is calculated from integrating the change in the groundwater drainage volume, $d x_{17} / d t$

$$
\frac{d x_{17}}{d t}=\left(\beta \cdot x_{2}-x_{3}\right) .86400
$$

Accumulated direct runoff water volume, $x_{18}\left(\mathrm{~m}^{3} \mathrm{~km}^{-2}\right)$, is calculated from integrating the change in the direct runoff water volume, $d x_{18} d t$

$$
\frac{d x_{18}}{d t}=\left(\alpha \cdot x_{2}-x_{1}\right) \cdot 86400
$$

Accumulated water flow input, $x_{19}\left(\mathrm{~m}^{3} \mathrm{~km}^{-2}\right)$, is calculated from integrating the change in the water flow input, $d x_{19} / d t$

$$
\frac{d x_{19}}{d t}=U_{1} .86400
$$

Accumulated water flow output, $x_{20}\left(\mathrm{~m}^{3} \mathrm{~km}^{-2}\right)$, is calculated from integrating the change in the water flow output, $d x_{20} / d t$

$$
\frac{d x_{20}}{d t}=\left((1-\alpha-\beta) \cdot x_{2}+x_{3}+x_{1}\right) \cdot 86400
$$

Accumulated $\mathrm{P}$ mass associated with plant organic $\mathrm{P}$ uptake, $x_{21}\left(\mathrm{~kg} \mathrm{P} \mathrm{km}^{-2}\right)$, is calculated from integrating the change in organic phosphorus plant-uptake, $d x_{21} / d t$

$$
\frac{d x_{21}}{d t}=C_{1} S_{1} S_{2} \frac{x_{4}}{V_{r}+x_{16}} 10^{6}
$$

Accumulated $\mathrm{P}$ mass associated with immobilisation $x_{22}$ $\left(\mathrm{kg} \mathrm{P} \mathrm{km}{ }^{-2}\right)$, is calculated from integrating the change in immobilisation, $d x_{22} / d t$

$$
\frac{d x_{22}}{d t}=C_{2} S_{2} \frac{x_{5}}{V_{r}+x_{16}} 10^{6}
$$

Accumulated $\mathrm{P}$ mass associated with mineralisation, $x_{23}$ $\left(\mathrm{kg} \mathrm{P} \mathrm{km}{ }^{-2}\right)$, is calculated from integrating the change in mineralisation, $d x_{23} / d t$

$$
\frac{d x_{23}}{d t}=C_{3} S_{2} \frac{x_{4}}{V_{r}+x_{16}} 10^{6}
$$

Accumulated $\mathrm{P}$ mass associated with plant inorganic $\mathrm{P}$ uptake, $x_{24}\left(\mathrm{~kg} \mathrm{P} \mathrm{km}^{-2}\right)$, is calculated from integrating the change in inorganic phosphorus plant-uptake, $d x_{24} / d t$

$$
\frac{d x_{24}}{d t}=C_{6} S_{1} S_{2} \frac{x_{5}}{V_{r}+x_{16}} 10^{6}
$$

The mass-balance within the land-phase is calculated and the results are displayed in INCA-P. The input to each land use in each reach is calculated as

$$
\text { Input }=x_{12}+x_{14}
$$

where $x_{12}$ depends on the daily organic fertiliser, livestock, wastewater and slurry additions, $\left(\mathrm{kg} \mathrm{P} \mathrm{km}^{-2}\right)$ and $x_{14}$ depends on the daily inorganic fertiliser additions $\left(\mathrm{kg} \mathrm{P} \mathrm{km}^{-2}\right)$.

The output from each land use in each reach is calculated as:

$$
\text { Output }=x_{13}+x_{15}+x_{21}+x_{24}
$$

where

$x_{13}=$ daily organic phosphorus leached $\left(\mathrm{kg} \mathrm{P} \mathrm{km}^{-2}\right)$;

$x_{15}=$ daily inorganic phosphorus leached $\left(\mathrm{kg} \mathrm{P} \mathrm{km}^{-2}\right)$;

$x_{21}=$ daily organic phosphorus taken up by plants ( $\mathrm{kg} \mathrm{P}$ $\mathrm{km}^{-2}$ );

$x_{24}=$ daily inorganic phosphorus taken up by plants $(\mathrm{kg} \mathrm{P}$ $\mathrm{km}^{-2}$ ).

The nitrogen stored in each land use in each reach is calculated as:

$$
\text { Storage }=x_{4}+x_{6}+x_{8}+x_{5}+x_{7}+x_{9}+x_{10}+x_{11}
$$

where

$x_{4}=$ readily-available organic phosphorus stored in soil $\left(\mathrm{kg} \mathrm{P} \mathrm{km}^{-2}\right)$;

$x_{6}=$ readily-available organic phosphorus stored in groundwater $\left(\mathrm{kg} \mathrm{P} \mathrm{km}^{-2}\right)$;

$x_{8}=$ readily-available organic phosphorus stored in direct runoff $\left(\mathrm{kg} \mathrm{P} \mathrm{km}^{-2}\right)$; 
$x_{5}=$ readily-available inorganic phosphorus stored in soil $\left(\mathrm{kg} \mathrm{P} \mathrm{km}^{-2}\right)$;

$x_{7}=$ readily-available inorganic phosphorus stored in groundwater $\left(\mathrm{kg} \mathrm{P} \mathrm{km}^{-2}\right)$;

$x_{9}=$ readily-available inorganic phosphorus stored in direct runoff $\left(\mathrm{kg} \mathrm{P} \mathrm{km}^{-2}\right)$;

$x_{10}=$ firmly-bound organic phosphorus stored in soil $\left(\mathrm{kg} \mathrm{P} \mathrm{km}^{-2}\right)$;

$x_{11}=$ firmly-bound inorganic phosphorus stored in soil $\left(\mathrm{kg} \mathrm{P} \mathrm{km}{ }^{-2}\right)$.

The initial nitrogen mass stored in each land use in each reach is calculated as:

$$
\text { Intitial }=x_{4,0}+x_{6,0}+x_{8,0}+x_{5,0}+x_{7,0}+x_{9,0}+x_{10,0}+x_{11,0}
$$

where

$x_{4,0}=$ readily-available organic phosphorus stored in soil at time, $\mathrm{t}=0\left(\mathrm{~kg} \mathrm{P} \mathrm{km}^{-2}\right)$;

$x_{6,0}=$ readily-available organic phosphorus stored in groundwater at time, $\mathrm{t}=0\left(\mathrm{~kg} \mathrm{P} \mathrm{km}^{-2}\right)$;

$x_{8,0}=$ readily-available organic phosphorus stored in direct runoff at time, $\mathrm{t}=0\left(\mathrm{~kg} \mathrm{P} \mathrm{km}^{-2}\right)$;

$x_{5,0}=$ readily-available inorganic phosphorus stored in soil at time, $\mathrm{t}=0\left(\mathrm{~kg} \mathrm{P} \mathrm{km}^{-2}\right)$;

$x_{7,0}=$ readily-available inorganic phosphorus stored in groundwater at time, $\mathrm{t}=0\left(\mathrm{~kg} \mathrm{P} \mathrm{km}^{-2}\right)$;

$x_{9,0}=$ readily-available inorganic phosphorus stored in direct runoff at time, $\mathrm{t}=0\left(\mathrm{~kg} \mathrm{P} \mathrm{km}^{-2}\right)$;

$x_{10,0}=$ firmly-bound organic phosphorus stored in soil at time, $\mathrm{t}=0\left(\mathrm{~kg} \mathrm{P} \mathrm{km}^{-2}\right)$;

$x_{11,0}=$ firmly-bound inorganic phosphorus stored in soil at time, $\mathrm{t}=0\left(\mathrm{~kg} \mathrm{P} \mathrm{km}^{-2}\right)$.

The user supplies all the initial values as input.

The phosphorus mass-balance for each land use in each reach is calculated as:

$$
\text { Bal = Initial }+ \text { Input }- \text { Output }- \text { Storage }
$$

If mass-balance is achieved, then $\mathrm{Bal}$ will equal zero.

The water balance for each land use in each reach is expressed as

$$
\begin{array}{r}
\mathrm{Bal}_{w}=\left(V_{r, 0}+x_{16,0}+x_{17,0}+x_{18,0}\right)+x_{19}-. \\
x_{20}-\left(V_{r}+x_{16}+x_{17}+x_{18}\right)
\end{array}
$$

where all the terms have been previously defined.

\section{Appendix B}

\section{IN-STREAM PHASE MASS-BALANCE CHECKS}

Accumulated reach volume, $x_{37}\left(\mathrm{~m}^{3}\right)$, is calculated from integrating the change in the reach volume, $d x_{3} / d t$

$$
\frac{d x_{37}}{d t}=\left(S_{4}+S_{5}+U_{7}-x_{25}\right) .86400
$$

Accumulated reach volume input, $x_{38}\left(\mathrm{~m}^{3}\right)$, is calculated from integrating the change in the reach volume input, $d x_{38}$ $d t$

$$
\frac{d x_{38}}{d t}=\left(S_{4}+S_{5}+U_{7}\right) \cdot 86400
$$

Accumulated reach volume output, $x_{39}\left(\mathrm{~m}^{3}\right)$, is calculated from integrating the change in the reach volume output, $d x_{39}$ $d t$

$$
\frac{d x_{39}}{d t}=x_{25} 86400
$$

Accumulated Total Phosphorus input to the reach, $x_{40}(\mathrm{~kg}$ $\mathrm{P})$, is calculated from integrating the change in the reach Total Phosphorus input, $d x_{40} / d t$

$$
\frac{d x_{40}}{d t}=P_{i n}
$$

Accumulated Total Phosphorus output from the reach, $x_{41}$ $(\mathrm{kg} \mathrm{P})$, is calculated from integrating the change in the reach Total Phosphorus output, $d x_{41} / d t$

$$
\frac{d x_{41}}{d t}=\frac{x_{33} x_{25} 86400}{x_{37}}
$$

Accumulated $\mathrm{P}$ mass associated with epiphyte uptake, $x_{42}$ $(\mathrm{kg} \mathrm{P})$, is calculated from integrating the change in epiphyte uptake, $d x_{42} / d t$

$$
\frac{d x_{42}}{d t}=\frac{C_{18} C_{15} \theta_{E}^{\left(U_{4}-20\right)} x_{32} x_{31} U_{11} a_{11} L w}{\left(C_{16}+a_{11}\right) \cdot 1000}
$$

Accumulated P mass associated with P exchange, $x_{43}(\mathrm{~kg}$ $\mathrm{P}$ ), is calculated from integrating the change in Total Phosphorus through exchange, $d x_{43} / d t$

$$
\frac{d x_{43}}{d t}=\frac{C_{19}}{1000}\left(a_{12}-a_{11}\right)
$$

Accumulated $\mathrm{P}$ mass associated with calcite coprecipitation, $x_{44}(\mathrm{~kg} \mathrm{P})$, is calculated from integrating the change in Total Phosphorus lost through calcite coprecipitation, $d x_{44} / d t$

$$
\frac{d x_{44}}{d t}=\frac{C_{20}}{1000} a_{11}
$$


Accumulated $\mathrm{P}$ mass associated with $\mathrm{P}$ gained from pore water, $x_{45}(\mathrm{~kg} \mathrm{P})$, is calculated from integrating the change in Total Phosphorus in water column gained from pore water, $d x_{45} / d t$

$$
\frac{d x_{45}}{d t}=\frac{1}{\rho_{s}(1-n) w L C_{20}} x_{34} \frac{d x_{27}}{d t}
$$

Accumulated $\mathrm{P}$ mass associated with $\mathrm{P}$ lost from water column, $x_{46}(\mathrm{~kg} \mathrm{P})$, is calculated from integrating the change in Total Phosphorus in water column lost to pore water, $d x_{46} d t$

$$
\frac{d x_{46}}{d t}=10^{-6} a_{11} K_{D}^{\text {SUS }} \frac{d x_{27}}{d t}
$$

All the rate co-efficients are temperature dependent, such that

$$
C_{n}=C 1.047^{\left(U_{4}-20\right)}
$$

where $U_{4}$ is the water temperature, which is assumed to equal the input air temperature.

The P mass-balance within the in-stream water-column component is calculated for each reach and the results are displayed on the load charts in INCA-P. The input to each reach, $i$ is calculated as:

$$
\text { Input }_{i}=x_{40, i}+x_{43, i}+x_{45, i}
$$

The output from each reach is calculated as:

$$
\text { Output }_{i}=x_{41, i}+x_{42, i}+x_{44, i}+x_{46, i}
$$

The $\mathrm{P}$ stored in each reach is calculated as:

$$
\text { Storage }_{i}=x_{33, i}
$$

where the terms are as defined previously.

The initial P mass stored in each reach is calculated as:

$$
\text { Initial }_{i}=x_{33,0, i}
$$

where

$$
x_{33,0, i}=\text { TP stored in reach, } i \text { at time, } \mathrm{t}=0(\mathrm{~kg} \mathrm{P}) ;
$$

The user supplies all the initial values as input.

The P mass-balance for each reach is calculated as:

$$
\text { Bal }_{i}=\text { Initial }_{i}+\text { Input }_{i}-\text { Output }_{i}-\text { Storage }_{i}
$$

Thus, if mass-balance is achieved then the balance will equal zero.

The initial water volumes and P loads are initialised using user-defined estimates of the river flow and the TP concentrations in the furthest upstream reach of the system. The volume of the furthest upstream reach (1) was initialised using the following equation:

$$
x_{37,0,1}=T_{4,0} x_{25,0,1} 86400
$$

where $T_{4^{\prime} 0}$ and $x_{25,0,1}$ are the time constant and user-defined initial flow at time, $t=0$ in the furthest upstream reach, respectively with the time constant being determined from $x_{25,0, i}$ using Eqn. (24).

The volume of the reach immediately downstream (2) was then initialised by running the model for the first time step, thereby integrating Eqn. (23) and adding the result to the, $x_{37,0}$ :

$$
x_{37,0,2}=\left(S_{4}+S_{5}+U_{7}-x_{25,0,2}\right) 86400+x_{37,0,1}
$$

Each of the subsequent reaches was initialised in turn by integrating Eqn. (23) for the first time step and adding the result to upstream volume. Once all the reach volumes were initialised, then the model was reset to run from day 1 for calibration or scenario analysis. Thus, by using this process it is assumed that the reach volumes on day, $t=0$ are the same on day $t=1$. Whilst this is clearly an approximation, it is necessary to produce a model run.

The water balance for reach, $i$ was expressed as

$$
B a l_{w, i}=x_{37,0, i}+x_{38, i}-x_{39, i}-x_{37, i}
$$

where $x_{37,0, i}$ is the initial volume of reach, $i$. 


\section{Appendix C}

THE DEFINITIONS OF THE REACH INPUTS

Total phosphorus input load to a reach, $\left(\mathrm{kg} \mathrm{P}\right.$ day $\left.^{-1}\right)$

$$
P_{i n}=86.4\left(\begin{array}{l}
S_{4} S_{6}+U_{7} U_{10}+\sum_{j=1}^{n} \text { area. }\left((1-\alpha-\beta) x_{1} a_{1}+x_{2} a_{3}+x_{3} a_{5}\right) \\
+\sum_{j=1}^{n} \operatorname{area} .\left((1-\alpha-\beta) x_{1} a_{2}+x_{2} a_{4}+x_{3} a_{6}\right)
\end{array}\right)
$$

where the lateral input flow to a reach from a sub-catchment, $\left(\mathrm{m}^{3} \mathrm{~s}^{-1}\right)$

$$
S_{5}=\sum_{j=1}^{n} \operatorname{area}\left((1-\alpha-\beta) x_{2}+x_{1}+x_{3}\right)
$$

for the $j^{\text {th }}$ of a total of $n$ land use types.

Boron input load to a reach, $\left(\mathrm{kg} \mathrm{Bday}^{-1}\right)$

$$
B_{\text {in }}=86.4\left(S_{4} S_{7}+U_{7} U_{9}\right)
$$

Sediment input load to a reach, $\left(\mathrm{kg} \mathrm{day}^{-1}\right)$

$$
S_{\text {in }}=86.4\left(S_{4} U_{8}\right)
$$

Live algae input load to a reach, $\left(\mu \mathrm{g} \mathrm{Chl} \mathrm{'a'} \mathrm{day}{ }^{-1}\right)$

$$
L_{\text {in }}=86.4 \cdot 10^{6}\left(S_{4} S_{8}\right)
$$

Dead algae input load to a reach, $\left(\mu \mathrm{g} \mathrm{Chl}\right.$ ' $\mathrm{a}$ ' $\left.\mathrm{day}^{-1}\right)$

$$
D_{\text {in }}=86.4 .10^{6}\left(S_{4} S_{9}\right)
$$

